\title{
Ice algae versus phytoplankton: resource utilization by Arctic deep sea macroinfauna revealed through isotope labelling experiments
}

\author{
Anni Mäkelä ${ }^{1, *}$, Ursula Witte $^{1}$, Philippe Archambault ${ }^{2,3}$ \\ ${ }^{1}$ Oceanlab, University of Aberdeen, Newburgh AB41 6AA, UK \\ ${ }^{2}$ Institut des Sciences de la mer de Rimouski, Université du Québec à Rimouski, Rimouski, QC G5L 3A1, Canada \\ ${ }^{3}$ Present address: Département de biologie, Université Laval, Québec, QC G1V 0A6, Canada
}

\begin{abstract}
Climate change is expected to change future Arctic marine primary production (PP) by reducing ice algal and increasing phytoplankton contributions. As most benthic macrofauna depend on PP from the euphotic zone for food, they could be vulnerable to changes in their food supply. To investigate the differential utilization of ice algae and phytoplankton food by benthic macroinfauna, isotope labelling experiments on dual ${ }^{13} \mathrm{C}-{ }^{15} \mathrm{~N}$ labelled ice algae and phytoplankton were carried out at 2 sites in the Canadian Arctic. After $4 \mathrm{~d}$, all animals collected at North Water Polynya (NOW; $709 \mathrm{~m}$ ) and Lancaster Sound (LS; $794 \mathrm{~m}$ ) exhibited isotope labelling. The C:N ratio of the macrofaunal biomassspecific uptake showed that all taxa were N-limited, and the uptake of algal $\mathrm{C}$ and $\mathrm{N}$ was often decoupled. Overall, the 2 macroinfaunal communities had different responses to the food items: in LS the accumulative biomass-specific uptake of phytoplankton $\mathrm{C}$ and $\mathrm{N}$ of all fauna was higher than uptake of ice algae, whereas in NOW ice algal $\mathrm{C}$ was more readily utilized. When taxa were examined individually, differences in food utilization by polychaetes, bivalves and crustaceans were site-specific, with no taxa exclusively exhibiting higher rates of ice algal uptake. The dietary plasticity observed between these sites suggests that benthic macroinfauna are able to efficiently utilize both ice algae and phytoplankton as a food source, and that the replacement of ice algae with phytoplankton food may not alter faunal feeding rates or their role in benthic nutrient cycling.
\end{abstract}

KEY WORDS: Climate change - Canadian Arctic Archipelago · C uptake · $\mathrm{N}$ uptake · Feeding experiment $\cdot$ Benthic $\cdot$ Macrofauna

*Corresponding author: anni.makela10@gmail.com

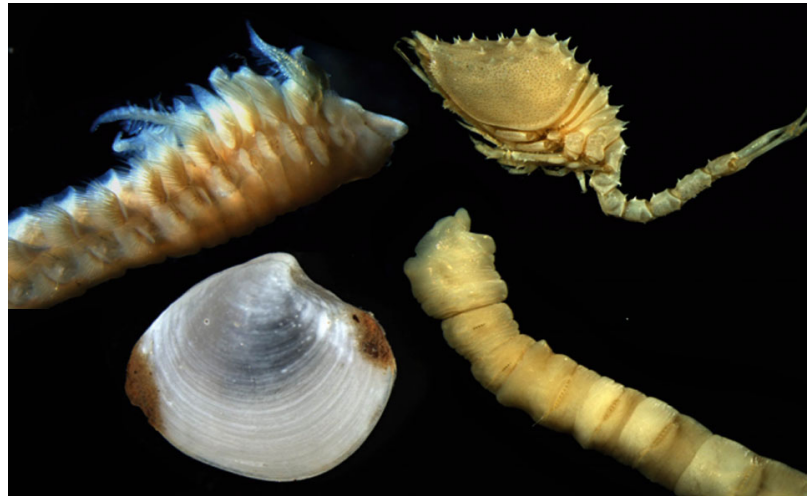

Arctic deep-sea sediments host diverse macroinvertebrate communities, which appear resilient to climate change mediated alterations in their food supply.

Photos: ( Laure de Montety \& Gonzalo Bravo

\section{INTRODUCTION}

Marine primary production (PP) in high latitudes is restricted to a short productive period when light levels are sufficient to enable algal growth. Summer sea ice extent controls the type, timing and magnitude of Arctic Ocean PP by limiting both light and habitat availability for the 2 main Arctic primary producers: ice algae living in association with the sea ice, and phytoplankton living in the water column (Leu et al. 2011). Ice algal blooms occur in the early Arctic spring, starting as soon as very low light levels become available but sea ice cover still persists. Ice break-up terminates the ice algal blooms, but enables phytoplankton blooms as light becomes available

(C) The authors 2017. Open Access under Creative Commons by Attribution Licence. Use, distribution and reproduction are unrestricted. Authors and original publication must be credited. 
with open water conditions (Leu et al. 2015). Historically, ice algae have contributed between 3 and $22 \%$ to overall PP in seasonally ice-covered regions (Gosselin et al. 1997, Hegseth 1998, Forest et al. 2011). Climate change is, however, warming the Arctic at an unprecedented rate (IPCC 2014), leading to such a fast summer sea ice loss that the region is likely to become free of summer sea ice by mid-century (Overland \& Wang 2013). The resulting earlier spring ice melt is likely to reduce ice algal PP (Arrigo et al. 2008, Søreide et al. 2010, Leu et al. 2011), while benefitting phytoplankton growth (Arrigo et al. 2008, Pabi et al. 2008). Largely due to the longer phytoplankton growth period, total Arctic marine PP has been increasing at an estimated rate of 1.4 to $6 \% \mathrm{yr}^{-1}$ since 1998 (Arrigo et al. 2008, Bélanger et al. 2013).

Deep-sea ecosystems are largely reliant on the export flux of organic matter from the euphotic zone as a food source (Ambrose \& Renaud 1995, Gooday 2002), and changes in both the quantity (Link et al. 2013a,b, Lovvorn et al. 2016) and quality (Hansen \& Josefson 2004, Byrén et al. 2006, Mayor et al. 2012, Morata et al. 2013) of the food arriving to the seafloor have been shown to significantly impact the composition and functioning of benthic communities. Ice algae are thought to provide an important early spring food source for benthic consumers (Tremblay et al. 2006, Morata et al. 2013, North et al. 2014), as temperature suppression of post-winter pelagic grazer growth allows for a high flux of intact ice algal cells to sink to the sea floor, tightly coupling benthic and pelagic processes (Coyle \& Pinchuk 2002, Hunt et al. 2002, Kirchman et al. 2005, Kędra et al. 2015). If the ice algal growth season is drastically shortened, the reduced ice algal food availability might negatively impact benthic consumers, especially as the replacement of ice algae by phytoplankton-derived organic matter (OM) can also affect the quality of the food. Virtually all polyunsaturated fatty acids (PUFAs) in the lipid-driven marine ecosystem originate from algae (Dalsgaard et al. 2003, Monroig et al. 2013). PUFAs are essential for the growth and reproduction of marine consumers (Hudson et al. 2004, McMahon et al. 2006, Jónasdóttir et al. 2009, Søreide et al. 2010, Leu et al. 2011), and therefore consumers must acquire PUFAs from their food. The relative proportion of PUFAs is usually higher in ice algae than in phytoplankton (Falk-Petersen et al. 1998, McMahon et al. 2006, Sun et al. 2009, Wang et al. 2014), making ice algae the superior quality food item.

Our current knowledge regarding the dietary importance of ice algae and phytoplankton to the Arctic benthic consumers is mainly based on studies that have used proxy techniques, such as natural stable isotope and biomarker analysis, to investigate the utilization of the 2 food items. These studies have shown that while the benthos in some areas seem to largely utilize ice algal food (Hobson et al. 2002, Brown \& Belt 2012, Søreide et al. 2013, Roy et al. 2015), the contributions of ice algae to consumer diets in other areas seem negligible (Hobson et al. 1995, Lovvorn et al. 2005, McTigue \& Dunton 2014, North et al. 2014, A. Mäkelä et al. unpubl. data). However, despite their usefulness in assessing longterm accumulation of different $\mathrm{C}$ sources into the consumer tissues, methodological restrictions associated with the analyses can make result interpretation difficult (Coffin et al. 1990, Brown \& Belt 2012), or introduce a seasonal sampling bias underestimating ice algal contributions to consumer diets (Kaufman et al. 2008). Experimental approaches can offer a complementary approach to investigating the food sources of benthic fauna. Feeding experiments involving subtidal or relatively shallow Arctic benthic communities have shown that both ice algae and phytoplankton are rapidly consumed (Sun et al. 2007), and that certain benthic macrofaunal species or feeding guilds selectively feed on the high quality ice algae (McMahon et al. 2006, Sun et al. 2009).

Isotope tracing experiments allow for a comparison of ice algae and phytoplankton uptake rates, directly assessing the differential consumption of both food types by benthic fauna. Dual labelling experiments on ${ }^{15} \mathrm{~N}$ and ${ }^{13} \mathrm{C}$ isotopes can overcome bias related to the fact that faunal nutrient demand can impact their food selection, consequently leading to decoupled uptake of different compounds from the food (Sun et al. 2007, Hunter et al. 2012). Dual labelling also allows quantification of the role of macrobenthos in benthic $C$ and $\mathrm{N}$ cycling, and an assessment of the potential impact of dietary change on these ecosystem services.

Here, we report on the results of 2 isotope tracing experiments conducted with deep-sea sediment communities from the North Water Polynya (NOW) and Lancaster Sound (LS) to assess the response of benthic macroinfaunal to ice algae and phytoplankton-derived OM. LS and NOW are among the deepest regions within the Canadian Arctic Archipelago (Kenchington et al. 2011, Roy et al. 2015), providing an interesting contrast to the shallow sites in the Chukchi Sea and Svalbard Archipelago where similar investigations have previously taken place (McMahon et al. 2006, Sun et al. 2007, 2009). Both sites are significant hotspots of Arctic macroinfaunal diversity and biomass (Thomson 1982, Link et al. 2013b, Mäkelä et al. unpubl. data), and are thus ideal for examining the 
Fig. 1. Locations of the sampling stations North Water Polynya (NOW; Stn 124) and Lancaster Sound (LS; Stn 323) in the Canadian Arctic Archipelago. Dashed line: estimated extents of the NOW and LS polynyas

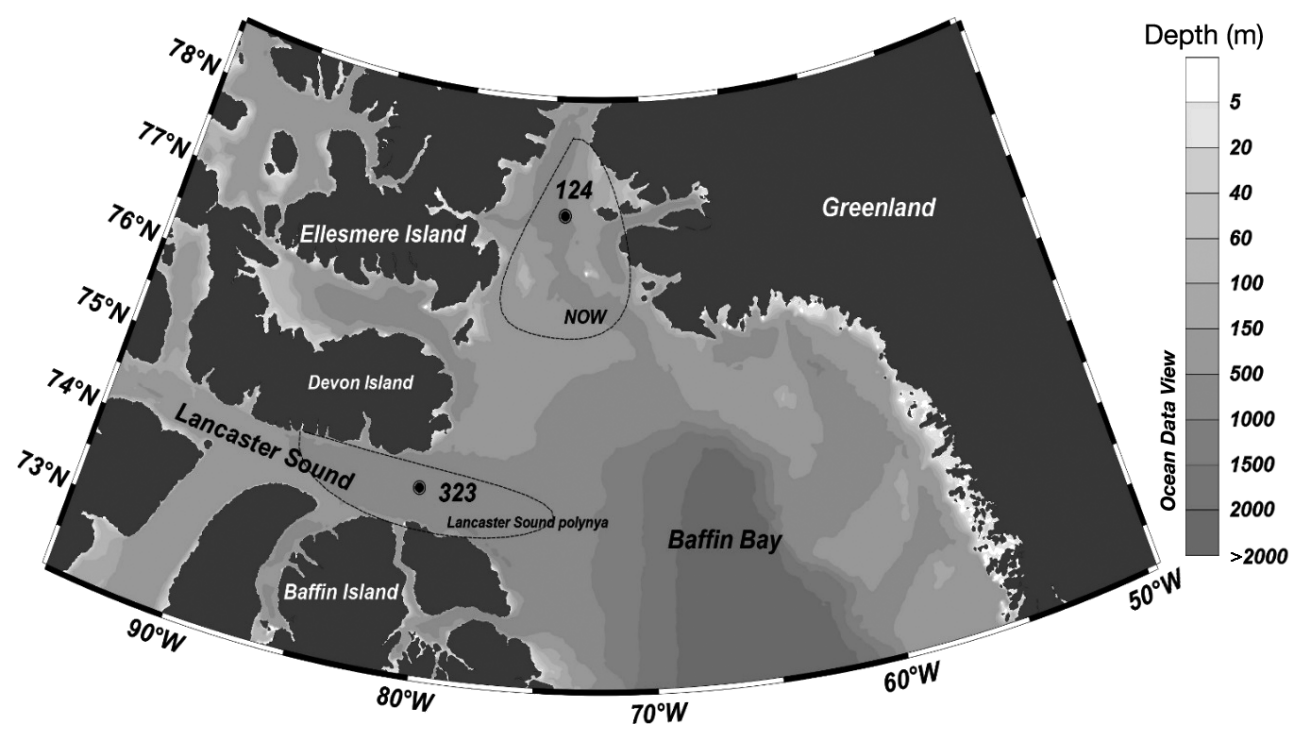

responses of a wide range of taxa to the 2 food sources. Additionally, natural stable isotope studies have suggested that both phytoplankton (Hobson \& Welch 1992, Mäkelä et al. unpubl. data) and ice algae (Hobson et al. 2002, Roy et al. 2015) are significant food sources for benthic fauna in the Canadian Arctic Archipelago, making NOW and LS interesting areas for directly comparing ice algal and phytoplankton uptake rates. The objectives of this study were to (1) quantify the uptake of ice algae and phytoplanktonderived $\mathrm{C}$ and $\mathrm{N}$ by benthic communities, (2) investigate differential processing of food items by different taxa and feeding guilds, and (3) investigate spatial differences in responses to the 2 types of food sources. Our hypothesis was that ice algae is the preferred food source for benthic macroinfauna at both sites, and thus the uptake of ice algae will be higher than the uptake of phytoplankton.

\section{MATERIALS AND METHODS}

\section{Sampling sites}

Field sampling took place during the ArcticNet 2013 cruise aboard the research icebreaker CCGS 'Amundsen'. The 2 sampling sites in NOW (Stn 124) and LS (Stn 323) are both situated in the western Baffin Bay region in the Canadian High Arctic (Fig. 1, Table 1). Both areas are among the most biologically productive regions in the Arctic Ocean (Stirling 1980, Hobson et al. 2002, Klein et al. 2002, Lalande et al. 2009, Roy et al. 2015), with estimated annual particulate organic carbon (POC) production of 60 and $254 \mathrm{~g} \mathrm{C} \mathrm{m}^{-2} \mathrm{yr}^{-1}$ in LS and eastern part of Northern Baffin Bay, respectively (Welch et al. 1992, Klein et al. 2002). Indeed, the maxima of the production in NOW can be an order of magnitude higher than in adjacent Baffin Bay waters (Tremblay et al. 2002, Caron et al. 2004). Phytoplankton dominates the annual PP at both sites, with ice algae contributing $10 \%$ to PP in LS and $3 \%$ in NOW (Welch et al. 1992, Michel et al. 2002a,b, Tremblay et al. 2006). Both sites thus fall within the typical range of 3 to $22 \%$ ice algal contribution reported for the seasonally ice covered parts of the Arctic (Gosselin et al. 1997, Hegseth 1998, Forest et al. 2011). Peak phytoplankton blooms occur in July/August and May/June in LS and NOW, respectively (Klein et al. 2002, Tremblay et al. 2002, Michel

Table 1. Sampling station, hydrographic and sediment characteristics in August 2013

\begin{tabular}{|c|c|c|}
\hline & $\begin{array}{l}\text { Lancaster } \\
\text { Sound }\end{array}$ & $\begin{array}{l}\text { North Water } \\
\text { Polynya }\end{array}$ \\
\hline ArcticNet 2013 station number & 323 & 124 \\
\hline Date sampled & 14 Aug 2013 & 27 Aug 2013 \\
\hline Depth $(\mathrm{m})$ & 794 & 709 \\
\hline Latitude & $74^{\circ} 9.41^{\prime} \mathrm{N}$ & $77^{\circ} 20.79^{\prime} \mathrm{N}$ \\
\hline Longitude & $80^{\circ} 28.32^{\prime} \mathrm{W}$ & $74^{\circ} 17.50^{\prime} \mathrm{W}$ \\
\hline Bottom $\mathrm{O}_{2}$ concentration $\left(\mathrm{ml} \mathrm{l}^{-1}\right)$ & 4.1 & 5.6 \\
\hline Bottom temperature $\left({ }^{\circ} \mathrm{C}\right)$ & 1.2 & -0.1 \\
\hline Bottom salinity & 34.5 & 34.4 \\
\hline $\begin{array}{l}\text { Macroinfaunal biomass } 0-10 \mathrm{~cm} \\
\left(\mathrm{mg} \mathrm{C} \mathrm{m}^{-2}\right)^{\mathrm{a}}\end{array}$ & $2110 \pm 345$ & $3190 \pm 432$ \\
\hline
\end{tabular}


et al. 2006). Physical characteristics of the sampling stations are shown in Table 1.

\section{Algal cultures}

Prior to the experiments, axenic cultures of pennate ice algae species Synedra hyperborea (CCMP 1422, Bigelow Laboratory for Ocean Sciences) and centric phytoplankton species Thalassiosira nordenskioeldii (CCMP 995, Bigelow Laboratory for Ocean Sciences) were grown in the lab at $0^{\circ} \mathrm{C}$ on a $12 \mathrm{~h}$ light:12 h dark cycle in $\mathrm{f} / 2$ artificial seawater media, amended with $50 \%{ }^{13} \mathrm{C}$-bicarbonate and $50 \%{ }^{15} \mathrm{~N}$ nitrate. Both species are common representatives of ice algal and phytoplankton communities in the Arctic Ocean (Horner \& Schrader 1982, von Quillfeldt 1997, Hegseth 1998, Lovejoy et al. 2002, von Quillfeldt et al. 2003, Ambrose et al. 2005, Tamelander et al. 2009), and Thalassiosira spp. are especially common in NOW (Booth et al. 2002). Centrifugationharvested algae were freeze dried and stored at $-80^{\circ} \mathrm{C}$ until the research cruise. The average $\mathrm{C}$ and $\mathrm{N}$ contents for $S$. hyperborea were 22.3 and $3.0 \%$, with a C:N ratio of 3.95, and for T. nordenskioeldii, 21.6 and $4.5 \%$, with a C:N ratio of 3.52 . The dried ice algae contained 60.1 at. $\%{ }^{13} \mathrm{C}$ and 36.5 at. $\%{ }^{15} \mathrm{~N}$, and the phytoplankton contained 53.8 at. $\%{ }^{13} \mathrm{C}$ and 45.9 at. $\%{ }^{15} \mathrm{~N}$.

\section{Sample collection and experimental design}

Two USNEL box corers $\left(0.25 \mathrm{~m}^{2}\right)$ were taken from the seafloor at each station to allow for the collection of 15 sediment cores $(40 \mathrm{~cm}$ tall, 9.4 to $10 \mathrm{~cm}$ diameter). Water temperature, salinity and dissolved oxygen concentrations were recorded $10 \mathrm{~m}$ above the seafloor with the ship's CTD profiler. The sediment level was $2 / 3$ of the sub-core depth, topped up with unfiltered bottom water collected from the same site. The sub-cores were sealed and left to settle for between 8 and $15 \mathrm{~h}$ before starting the experiment. The water was continuously stirred during the experiments with magnetic rods attached to the core lids. At the onset of the experiments, the algae were suspended in bottom seawater collected at the sampling stations, and added to the experimental cores using a hypodermic needle to allow for an even distribution on the sediment surface. At each station, 3 cores were used as controls without algal addition, 6 cores received ice algae and 6 cores phytoplankton. The amount of algae added to the cores represented $25 \%$ of the estimated annual POC flux at each study region (Lalande et al. 2009), with NOW receiving the equivalent of $1475 \mathrm{mg} \mathrm{C} \mathrm{m}^{-2}$, and $\mathrm{LS}, 600 \mathrm{mg} \mathrm{C} \mathrm{m}^{-2}$. To our knowledge, no direct POC export flux measurements for LS exist, and therefore the export flux data of Cape Bathurst Polynya was used as a reference point (Lalande et al. 2009). All 3 sites are known eutrophic hotspots in the Canadian Arctic, with the PP rates in Cape Bathurst Polynya placing between the rates of NOW and LS (Arrigo \& van Dijken 2004, Ardyna et al. 2011). As the benthic-pelagic coupling in NOW and LS, however, appears tighter than in Cape Bathurst Polynya (Darnis et al. 2012), this polynya was thought to be the best proxy for POC flux in LS in the absence of in situ measurements. The algal dose added to the cores was calculated according to the algal $\mathrm{C}$ content, and therefore the amount of algal $\mathrm{N}$ added varied according to the $\mathrm{C}: \mathrm{N}$ ratios. In NOW, $198 \mathrm{mg} \mathrm{N} \mathrm{m}^{-2}$ (ice algae) and $305 \mathrm{mg}$ $\mathrm{N} \mathrm{m}^{-2}$ (phytoplankton) were added, and in LS the doses were $81 \mathrm{mg} \mathrm{N} \mathrm{m}^{-2}$ (ice algae) and $124 \mathrm{mg} \mathrm{N}$ $\mathrm{m}^{-2}$ (phytoplankton).

The cores were incubated for $4 \mathrm{~d}$, during which they were kept in darkness at $4^{\circ} \mathrm{C}$. Oxygen concentration was monitored during the experiment using oxygen dipping probes (DP-PSt3 and Fibox 3 LCD-trace v6; PreSens) inserted in the cores via an opening in the core lids. At the end of incubation, the cores were sliced at 0 to 5 and 5 to $10 \mathrm{~cm}$ sediment horizons, and half of the top $5 \mathrm{~cm}$ slice was sieved through a $500 \mu \mathrm{m}$ mesh to collect macrofaunal-sized animals for the tissue $\mathrm{C}^{13}$ and ${ }^{15} \mathrm{~N}$ tracer analysis, whereas the other half was used for phospholipid fatty acid analysis (A. Mäkelä et al. unpubl. data). For the 5 to $10 \mathrm{~cm}$ layer, the entire core was used for macrofauna collection. The collected macrofauna were preserved in $4 \%$ buffered seawater formalin until analysis.

\section{Sample preparation}

In LS, bivalves and polychaetes were the dominant taxa by abundance and biomass, whereas in NOW, polychaetes dominated the community biomass but crustaceans were the most abundant taxa (A. Mäkelä et al. unpubl. data). Specimens were identified to lowest possible taxonomic level, and when appropriate, assigned one of the following feeding guilds: facultative filter feeder/surface deposit feeder (FF/SDF), filter feeder (FF), predator/scavenger (P/S), subsurface deposit feeder (SSDF) or surface deposit feeder (SDF). Feeding guild identification was according to the literature sources (Fauchald \& Jumars 1979, Link 
et al. 2013b; WoRMS, www.marinespecies.org, accessed 19 September 2016). For the isotope signature calculations, cores were treated as replicate measurements, and all individuals of the same taxa in a particular core were combined together, dried, homogenized and analyzed as 1 sample. Invertebrate samples with carbonate structures were acidified in silver cups by adding drops of $1 \mathrm{M} \mathrm{HCl}$ to the samples until the samples stopped bubbling, indicating the calcareous structures and exoskeletons had been dissolved (Yokoyama et al. 2005), and then allowed to dry without rinsing (Mateo et al. 2008). Due to the small size of the individuals, most samples had to be pooled at family (polychaetes and crustaceans) or phylum level (other taxa), with the exception of the dominant polychaete species Prionospio cirrifera, which could be analyzed separately. Echinoderm samples collected were extremely small, and samples from 5 different phytoplankton-addition cores in NOW had to be pooled together for analysis. The combined uptake by echinoderms was then divided between the 5 cores for total community and echinoderm uptakes. Samples from the 0 to 5 and 5 to $10 \mathrm{~cm}$ layers were analyzed separately, but the values were combined for the core average calculations during data analysis. In each core, unidentified faunal fragments were also pooled together for $\delta^{13} \mathrm{C}$ and $\delta^{15} \mathrm{~N}$ signatures. The samples were simultaneously analyzed for ${ }^{13} \mathrm{C}-{ }^{15} \mathrm{~N}$ isotopic signatures due to limited sample biomass. All samples, including acidified samples in silver cups, were encapsulated in tin cups for analysis.

\section{$\delta^{13} \mathrm{C}$ and $\delta^{15} \mathrm{~N}$ analysis and calculations}

The total $\mathrm{C}$ and $\mathrm{N}$ concentrations and the $\delta^{13} \mathrm{C}$ and $\delta^{15} \mathrm{~N}$ natural abundance isotope ratios of the pooled animal samples were determined using a PDZ Europa ANCA-GSL elemental analyser interfaced to a PDZ Europa 20-20 isotope ratio mass spectrometer (Sercon). During analysis, the samples were interspersed with several replicates of at least 4 different National Institute of Standards and Technology (NIST) laboratory standards (glutamic acid GLU, Nylon 5, USGS-41 glutamic acid, REF5 FIVER, IsoLife maize, bovine liver), which have previously been calibrated against NIST standard reference materials (IAEAN1, IAEA-N2, IAEA-N3, USGS-40 and USGS-41). Long-term $\mathrm{SD}$ for the stable isotope measurements was $0.2 \%$ for ${ }^{13} \mathrm{C}$ and $0.3 \%$ for ${ }^{15} \mathrm{~N}$.

Stable isotope values are expressed in $\delta$ notation $(\%)$ relative to the reference material according to the equation:

$$
\delta X(\%)=\left(R_{\text {sample }}-R_{\text {reference }}\right)-1 \times 1000
$$

where $X$ is ${ }^{15} \mathrm{~N}$ or ${ }^{13} \mathrm{C}, R_{\text {sample }}$ is the ${ }^{13} \mathrm{C}:{ }^{12} \mathrm{C}$ or ${ }^{15} \mathrm{~N}:{ }^{14} \mathrm{~N}$ ratio of the sample and $R_{\text {reference }}$ is the ${ }^{13} \mathrm{C}:{ }^{12} \mathrm{C}$ or ${ }^{15} \mathrm{~N}:{ }^{14} \mathrm{~N}$ ratio of the reference material for $\mathrm{C}$ or $\mathrm{N}$. The international reference material for $\mathrm{C}$ is the Vienna Pee Dee Belemnite $\left(R_{\mathrm{VPDB}}=0.0112372\right)$ and for $\mathrm{N}$ it is the isotopic ratio of atmospheric $\mathrm{N}_{2}\left(R_{\mathrm{atmN}}=0.0036765\right)$.

As the animals were preserved in formalin and this is known to alter $\mathrm{C}$ isotope ratios (Bosley \& Wainright 1999), the $\delta^{13} \mathrm{C}$ signatures obtained were corrected by adding $1 \%$ to each value (Sarakinos et al. 2002). ${ }^{15} \mathrm{~N}$ values were not corrected as the effects of formalin preservation has been shown to be minor (Sarakinos et al. 2002). The effect of preservation is, however, negligible compared to the tracer signature.

To quantify the uptake of algal biomass by the benthos, the incorporation of ${ }^{13} \mathrm{C}$ or ${ }^{15} \mathrm{~N}(I)$ into macrofaunal tissue was calculated from the excess ${ }^{13} \mathrm{C}$ or ${ }^{15} \mathrm{~N}(E)$ and the biomass of the specimen (in $\mathrm{C}$ or $\mathrm{N}$ units) (Moodley et al. 2005), using the formula:

$$
I=E \times \text { specimen biomass }
$$

The specimen $\mathrm{C}$ and $\mathrm{N}$ biomass was derived from the dry mass of the specimens and the $\mathrm{C}$ and $\mathrm{N}$ content from the IRMS. $E$ was calculated as:

$$
E=F_{\text {sample }}-F_{\text {background }}
$$

where $F=R /(R+1)$ and $R=\left(\delta^{13} \mathrm{C} / 1000+1\right) \times$ reference material (Vienna Pee Dee Belemnite $=$ $0.0112372)$, or $R=\left(\delta^{15} \mathrm{~N} / 1000+1\right) \times$ reference material (atmospheric $\mathrm{N}_{2}=0.0036765$ ).

The final uptake of algae ( $\left.I_{\text {algae }}\right)$ was then calculated as a quotient of the algal labelling factor for ice algae and phytoplankton (ice algae: 60.1 at. $\%{ }^{13} \mathrm{C}$ and 36.5 at. $\%{ }^{15} \mathrm{~N}$, phytoplankton 53.8 at. $\%{ }^{13} \mathrm{C}$ and 45.9 at. $\%{ }^{15} \mathrm{~N}$ ) following the equation:

$$
I_{\text {algae }}=I / \text { labelling factor }
$$

For background isotope measurements, at each station the closest non-labeled taxonomic relative of each enriched macrofauna sample collected from the background cores was used for the calculations. For $P$. cirrifera the same species was used as a reference material, but for most samples, the genus or family level average was used for the calculations. Taxa identified to phylum, class or order level were compared with their background core counterparts. Both the total uptake (absolute value of measured algal C and $\mathrm{N}$ uptake) and the biomass-specific uptake (indicating uptake 'efficiency'), were calculated. In LS, 3 megafaunal-sized bivalves (2 Bathyarca glacialis and 1 Astartidae individual, only observations of each taxa at the site) were removed from the uptake cal- 
culations due to their extremely high biomass and uptake rates. The biomass-specific uptake was calculated for all samples, including the 3 large bivalves.

\section{Statistical analysis}

The 2 stations were investigated separately due to differences in the absolute amount of algal biomass added to the cores at the sites. Statistical tests were conducted for the whole community uptake, for each tested taxon (polychaetes, crustaceans, bivalves and pooled 'other' that included all other minority taxa, except the pooled echinoderm uptake from NOW phytoplankton cores) and for each feeding guild (FF/SDF, P/S, SDF and SSDF), except for FF where the number of replicates was not sufficient for statistical analysis. Additionally, the high abundance of polychaetes from the Family Spionidae allowed for their uptake of algae to be compared. For each analysis, differences in the total and biomassspecific $\mathrm{C}$ and $\mathrm{N}$ uptakes between ice algae and phytoplankton treatments were tested using an independent samples $t$-test, or when assumptions were not met, using a Mann-Whitney $U$-test. Normality of the data residuals was tested using the Shapiro-Wilk test and the homogeneity of residual variance was evaluated visually. See Tables 2 \& 3 for data that were $\log _{10}$ transformed to reach the normality assumption. Due to the small and uneven sample sizes and small deviations in equality of variance, a Welch correction was used for comparisons when appropriate (Quinn \& Keough 2002). Due to high natural variability in uptake rates between the cores, the results are reported at both $\mathrm{p}<0.05$ and $\mathrm{p}<0.10$ significance levels. Where $0.10<\mathrm{p}>0.05$, the exact result is explicitly stated in the text.

\section{RESULTS}

\section{Total macroinfaunal uptake of ice algae and phytoplankton $\mathrm{C}$ and $\mathrm{N}$}

The uptake of both ice algae and phytoplankton was rapid, and all of the macrofauna samples showed ${ }^{13} \mathrm{C}$ - and ${ }^{15} \mathrm{~N}$-label uptake after $4 \mathrm{~d}$ of incubation, except 2 individuals (1 Scaphopoda mollusc and 1 Syllidae polychaete) in LS which were only ${ }^{15} \mathrm{~N}$ labelled. On average, the macrofaunal community took up $7.9 \pm 1.8 \mathrm{mg} \mathrm{C} \mathrm{m}^{-2}$ and $1.2 \pm 0.3 \mathrm{mg} \mathrm{N} \mathrm{m}^{-2}$ in the ice algae cores, and $4.3 \pm 0.9 \mu \mathrm{g} \mathrm{C} \mathrm{m}^{-2}$ and $0.8 \pm$ $0.2 \mathrm{mg} \mathrm{N} \mathrm{m}^{-2}$ in the phytoplankton cores in NOW
(Fig. 2). This uptake corresponds to $0.5 \pm 0.1$ and 0.6 $\pm 0.2 \%$ of the total $\mathrm{C}$ and $\mathrm{N}$ added to ice algae cores, respectively, and $0.3 \pm 0.1 \%$ of both $\mathrm{C}$ and $\mathrm{N}$ added to phytoplankton cores. No statistically significant difference in total $\mathrm{C}$ and $\mathrm{N}$ total uptake between the treatments was found (Table 2).

The total macrofaunal uptake of algae in LS were assessed without the contribution of 3 megafaunalsized bivalves, as their contributions to core biomass and uptake (4 $\mathrm{mg} \mathrm{C} \mathrm{m} \mathrm{C}^{-2}$ of ice algae and 11 and $25 \mathrm{mg} \mathrm{C} \mathrm{m}{ }^{-2}$ of phytoplankton each) were higher than the combined uptake of all other infauna in the cores. Without those bivalves, average uptake in the ice algae cores in LS was $3.1 \pm 1.0 \mathrm{mg} \mathrm{C} \mathrm{m}^{-2}$ and 0.3 $\pm 0.1 \mathrm{mg} \mathrm{N} \mathrm{m}^{-2}$, and in phytoplankton cores the uptake was $3.3 \pm 0.4 \mathrm{mg} \mathrm{C} \mathrm{m}{ }^{-2}$ and $0.6 \pm 0.1 \mathrm{mg} \mathrm{N} \mathrm{m}^{-2}$ (Fig. 2). This represented $0.5 \pm 0.2 \%$ of added $\mathrm{C}$ and $0.4 \pm 0.1 \%$ of added $\mathrm{N}$ in ice algae cores, and $0.6 \pm$ $0.1 \%(\mathrm{C})$ and $0.5 \pm 0.1 \%(\mathrm{~N})$ in phytoplankton cores. No statistically significant difference in C uptake between the treatments was found (Table 3), but the total phytoplankton $\mathrm{N}$ uptake was significantly higher than uptake of ice algal $\mathrm{N}(\mathrm{p}=0.063)$.

In NOW, polychaetes dominated the total uptake of ice algal and phytoplankton $\mathrm{C}$ and $\mathrm{N}$, and additionally, bivalves were significant in the uptake of ice algae (Fig. 3). No taxa showed significant differences in ice algae and phytoplankton-derived $\mathrm{C}$ and $\mathrm{N}$ uptake except crustaceans, which took up more phytoplankton than ice algal-derived N ( $p=0.055$; Table 2). In LS, the total uptake of $\mathrm{C}$ and $\mathrm{N}$ from both algae was dominated by polychaetes (Fig. 3). The total uptakes of ice algae-derived $\mathrm{C}$ and $\mathrm{N}$ by crustaceans were significantly higher than uptake of phytoplankton (Table 3). The other taxa compared did not show significant differences in $\mathrm{C}$ and $\mathrm{N}$ uptakes between treatments.

In NOW, the majority $(>70 \%)$ of the ice algaederived $\mathrm{C}$ and $\mathrm{N}$ was taken up by individuals belonging to the family Spionidae, with other families making minor contributions (Fig. 4). In the phytoplankton cores, spionids and a single terebellid recovered in one of the experimental cores were responsible for the majority of the total phytoplankton $\mathrm{C}$ and $\mathrm{N}$ uptake. In NOW, $11 \%$ of uptake was attributed to unidentified polychaete fragments. The uptake of ice algal $C$ by spionids was significantly higher than uptake of phytoplankton ( $p=0.065)$, but no difference in $\mathrm{N}$ uptake was found (Table 2). Also in LS, the family Spionidae was responsible for majority of the phytoplankton and ice algae-derived $\mathrm{C}$ and $\mathrm{N}$ uptake (Fig. 4), but no statistically significant difference in their uptake between treatments was found 

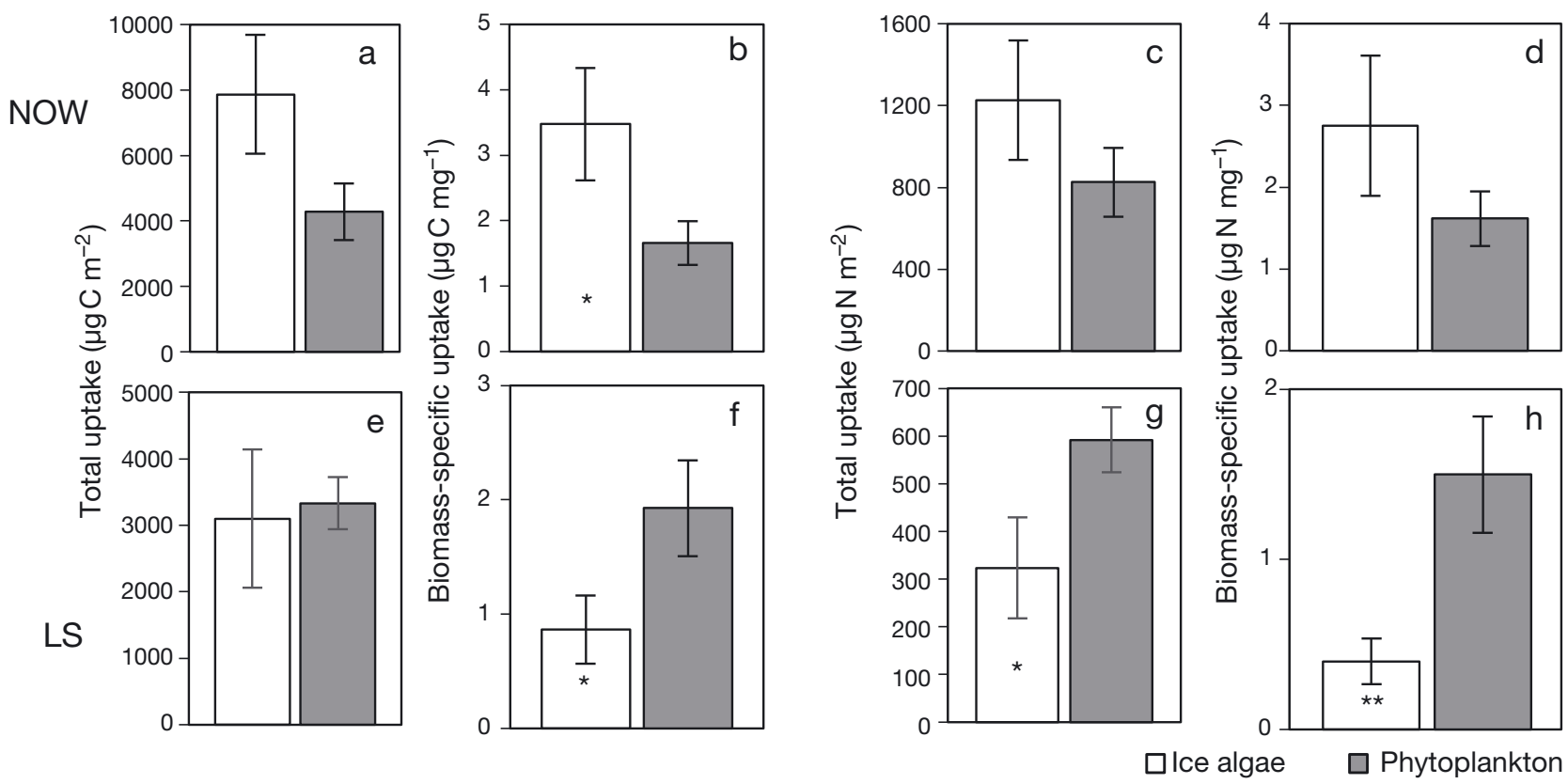

Fig. 2. Mean $( \pm \mathrm{SE})$ total and biomass-specific uptake of ice algae and phytoplankton-derived $\mathrm{C}$ and $\mathrm{N}$ by macroinfaunal communities at $(\mathrm{a}-\mathrm{d})$ North Water Polynya (NOW) and $(\mathrm{e}-\mathrm{h})$ Lancaster Sound (LS). Differences in uptake between treatments were determined using an independent samples $t$-test; significant differences are indicated with asterisks: ${ }^{*} \mathrm{p}<0.10 ;{ }^{* *} \mathrm{p}<0.05$

(Table 3). Contributions of other families to the total uptake of algae were minimal, and unidentified polychaete fragments accounted for $\sim 17 \%$ of total $\mathrm{C}$ and $\mathrm{N}$ uptake in both treatment cores.

Total uptake of both algal types in NOW was dominated by FF/SDF (Fig. 5). The FF/SDF uptake of ice algal $C$ appeared higher than uptake of phytoplankton $\mathrm{C}(\mathrm{p}=0.076)$, but no difference in $\mathrm{N}$ uptake was found (Table 2). The $\mathrm{C}$ or $\mathrm{N}$ uptakes of other feeding guilds were not significantly different between the treatments. FF/SDF also dominated the uptake of both algal types in LS, but additionally, uptake by FF in one of the phytoplankton cores was high (Fig. 5). No significant differences in total feeding guildspecific $\mathrm{C}$ and $\mathrm{N}$ uptake between treatments was found (Table 3).

Table 2. Statistical analysis comparing ice algae and phytoplankton-derived C and N uptakes for whole community, individual taxa and individual feeding guilds in North Water Polynya. FF/SDF: filter/surface deposit feeder; SDF: surface deposit feeder; SSDF: subsurface deposit feeder; P/S: predator/scavenger. $U$ : Mann-Whitney $U$-test was applied instead of an independent samples $t$-test

\begin{tabular}{|c|c|c|c|c|c|c|c|c|c|c|c|c|}
\hline & \multicolumn{3}{|c|}{ Total C uptake } & \multicolumn{3}{|c|}{ Total N uptake } & \multicolumn{3}{|c|}{ Biomass-specific C uptake } & \multicolumn{3}{|c|}{ Biomass-specific $\mathrm{N}$ uptake } \\
\hline & $t$ & df & $\mathrm{p}$ & $t$ & df & $\mathrm{p}$ & $t$ & $\mathrm{df}$ & $\mathrm{p}$ & $t$ & df & $\mathrm{p}$ \\
\hline Whole community & 1.461 & 10 & $0.175^{\mathrm{a}}$ & 0.857 & 10 & $0.411^{\mathrm{a}}$ & 1.971 & 6.474 & 0.093 & 1.652 & 6.597 & 0.145 \\
\hline \multicolumn{13}{|l|}{ Taxa } \\
\hline Polychaete & 1.643 & 10 & $0.131^{\mathrm{a}}$ & 1.209 & 10 & 0.254 & 1.950 & 8.161 & 0.086 & 1.390 & 9.488 & 0.196 \\
\hline Crustacea & -1.624 & 10 & $0.135^{\mathrm{a}}$ & -2.171 & 10 & $0.055^{\mathrm{a}}$ & $U=6.000$ & & 0.065 & $U=3.000$ & & 0.015 \\
\hline \multicolumn{13}{|l|}{ Feeding guild } \\
\hline $\mathrm{FF} / \mathrm{SDF}$ & 1.980 & 10 & $0.076^{\mathrm{a}}$ & 1.537 & 10 & 0.155 & 0.726 & 9.996 & $0.484^{\mathrm{a}}$ & 0.231 & 9.997 & 0.822 \\
\hline $\mathrm{SDF}$ & -0.186 & 8.999 & $0.857^{a}$ & -0.198 & 8.866 & 0.847 & 0.323 & 8.975 & $0.754^{\mathrm{a}}$ & 0.282 & 8.919 & $0.784^{\mathrm{a}}$ \\
\hline SSDF & 1.233 & 9 & $0.249^{\mathrm{a}}$ & 1.482 & 8.741 & $0.173^{\mathrm{a}}$ & $U=8.000$ & & 0.247 & 1.065 & 6.394 & $0.325^{\mathrm{a}}$ \\
\hline $\mathrm{P} / \mathrm{S}$ & 0.102 & 4.149 & 0.924 & 0.021 & 5 & $0.984^{\mathrm{a}}$ & 0.967 & 4.749 & $0.380^{\mathrm{a}}$ & 0.752 & 4.486 & 0.490 \\
\hline
\end{tabular}


Table 3. Results for statistical analysis comparing ice algae and phytoplankton-derived C and N uptakes for whole community, individual taxa and individual feeding guilds in Lancaster Sound. FF/SDF: filter/surface deposit feeder; SDF: surface deposit feeder; SSDF: subsurface deposit feeder; P/S: predator/scavenger. $U$ : Mann-Whitney $U$-test was applied instead of an independent samples $t$-test

\begin{tabular}{|c|c|c|c|c|c|c|c|c|c|c|c|c|}
\hline & \multicolumn{3}{|c|}{ Total C uptake } & \multicolumn{3}{|c|}{ Total N uptake } & \multicolumn{3}{|c|}{ Biomass-specific C uptake } & \multicolumn{3}{|c|}{ Biomass-specific N uptake } \\
\hline & $t$ & df & $\mathrm{p}$ & $t$ & $\mathrm{df}$ & $\mathrm{p}$ & $t$ & $\mathrm{df}$ & $\mathrm{p}$ & $t$ & df & $\mathrm{p}$ \\
\hline Whole community & -0.210 & 6.393 & 0.840 & -2.132 & 8.579 & 0.063 & -2.064 & 9.006 & 0.069 & -2.980 & 6.504 & 0.022 \\
\hline \multicolumn{13}{|l|}{ Taxa } \\
\hline Polychaete & -0.051 & 8.282 & 0.961 & -1.666 & 10 & 0.127 & -1.104 & 9.470 & 0.528 & -2.015 & 9.421 & 0.073 \\
\hline Crustacea & 2.885 & 8.410 & $0.019^{\mathrm{a}}$ & 2.432 & 8.576 & $0.039^{\mathrm{a}}$ & 3.916 & 4.592 & 0.027 & 2.458 & 5.978 & 0.049 \\
\hline Bivalve & -0.277 & 6.374 & $0.790^{\mathrm{a}}$ & -1.079 & 6.650 & $0.318^{\mathrm{a}}$ & -2.052 & 8.887 & 0.071 & -3.376 & 10 & $0.007^{a}$ \\
\hline Other & 0.280 & 7.558 & $0.787^{\mathrm{a}}$ & -0.611 & 7.340 & $0.560^{\mathrm{a}}$ & -1.051 & 9.072 & $0.320^{\mathrm{a}}$ & -1.279 & 9.118 & $0.233^{\mathrm{a}}$ \\
\hline \multicolumn{13}{|l|}{ Feeding guild } \\
\hline FF/SDF & -0.017 & 8.485 & 0.987 & -1.504 & 9.500 & 0.165 & -1.694 & 10 & 0.121 & -3.021 & 10 & $0.013^{\mathrm{a}}$ \\
\hline $\mathrm{SDF}$ & $U=12.000$ & & 0.394 & 0.064 & 9.451 & $0.950^{\mathrm{a}}$ & -0.813 & 8.766 & $0.438^{\mathrm{a}}$ & -1.232 & 9.236 & $0.248^{\mathrm{a}}$ \\
\hline SSDF & $U=16.000$ & & 0.818 & $U=16.000$ & & 0.818 & 0.351 & 9.615 & 0.733 & -0.477 & 8.694 & $0.645^{\mathrm{a}}$ \\
\hline $\mathrm{P} / \mathrm{S}$ & $U=11.000$ & & 0.310 & 0.119 & 8.787 & $0.908^{\mathrm{a}}$ & $U=11.500$ & & 0.310 & $U=7.500$ & & 0.093 \\
\hline Spionidae & -0.217 & 10 & 0.833 & -1.675 & 10 & 0.125 & -1.67 & 9.208 & 0.129 & -2.964 & 6.158 & 0.024 \\
\hline
\end{tabular}

\section{Biomass-specific uptake of ice algae and phytoplankton $\mathrm{C}$ and $\mathrm{N}$}

An opposite trend of ice algae and phytoplankton biomass-specific uptake was found between LS and NOW (Fig. 2). In NOW, ice algae were taken up more readily than phytoplankton $(3.5 \pm 0.9$ vs. $1.7 \pm 0.3 \mu \mathrm{g}$ $\mathrm{C} \mathrm{mg}^{-1}$ and $2.7 \pm 0.6$ vs. $1.6 \pm 0.3 \mu \mathrm{g} \mathrm{N} \mathrm{mg}^{-1}$ ), whereas in LS, phytoplankton uptake was higher than uptake of ice algae $\left(1.9 \pm 0.4\right.$ vs. $0.9 \pm 0.3 \mu \mathrm{gC} \mathrm{mg}^{-1}$ and $1.5 \pm 0.3$ vs. $0.4 \pm 0.1 \mu g \mathrm{~N} \mathrm{mg}^{-1}$ ). Biomass-specific $\mathrm{C}$ uptake in NOW was higher in ice algae treatment cores than in phytoplankton cores $(p=0.093)$, but no difference in $\mathrm{N}$ uptake was found between treatments (Table 2). In LS, the biomass-specific uptakes of phytoplankton $\mathrm{C}(\mathrm{p}=0.069)$ and $\mathrm{N}(\mathrm{p}=0.022$; Table 3 ) were significantly higher than uptakes of ice algae-derived $\mathrm{C}$ or $\mathrm{N}$ (Fig. 2).

In NOW, especially the bivalve biomass-specific uptake of ice algae and phytoplankton-derived $\mathrm{C}$ and $\mathrm{N}$ by was high (Fig. 3). Additionally, the echinoderms in phytoplankton cores had biomass-specific uptakes of up to $9.7 \mu \mathrm{g} \mathrm{C} \mathrm{mg}^{-1}$ and $5.1 \mu \mathrm{g} \mathrm{N} \mathrm{mg}{ }^{-1}$, suggesting they were highly efficient in algal processing. They were, however, not included in the statistical analysis of the pooled 'other' taxa uptakes between the treatments, as this would have skewed the results to only reflect the echinoderm uptake from this single measurement. The bivalve and pooled 'other taxa' uptakes were thus not significantly different between treatments, whereas polychaetes took up more ice algal C $(p=0.086)$ and crustaceans both phytoplankton $C$ $(\mathrm{p}=0.065)$ and $\mathrm{N}(\mathrm{p}<0.05 ;$ Table 2$)$.
In LS, the biomass-specific uptake in ice algae cores was dominated by crustaceans, and their uptake of ice algal $\mathrm{C}$ and $\mathrm{N}$ was significantly higher than uptake of phytoplankton (Fig. 3, Table 3). Echinoderms dominated the phytoplankton uptake, but no statistical comparisons between treatments could be made due to low sample size. The $\mathrm{C}$ uptake of polychaetes was not different between the treatments, but phytoplankton-derived $\mathrm{N}$ uptake was higher compared to ice algae $(p=0.073$; Table 3$)$. Additionally, bivalve biomass-specific uptakes of $\mathrm{C}$ $(p=0.071)$ and $N(p=0.007)$ were significantly higher in phytoplankton cores compared to ice algae cores.

At both sites, spionids dominated the biomassspecific uptake of both ice algal and phytoplankton C and N (Fig. 4). The Family Sabellidae was additionally important in algal uptake at both sites, whereas Families Orbiniidae and Chaetopteridae were significant in NOW and LS, respectively. In NOW, no significant differences in spionid $\mathrm{C}$ and $\mathrm{N}$ uptake between the treatments were found (Table 2). In LS however, phytoplankton-derived $\mathrm{N}$ was more readily assimilated by the spionids (Table 3 ).

FF/SDF and FF dominated the biomass-specific uptake of both algal types at both sites, and contributions of other feeding guilds were negligible (Fig. 5). In NOW, no statistically significant differences between the biomass-specific uptakes of ice algae and phytoplankton were found for any of the feeding guilds (Table 2). In LS, the FF/SDF $(\mathrm{p}<0.05)$ and P/S $(p=0.093)$ uptakes of phytoplankton $\mathrm{N}$ were, however, significantly higher than the uptake of ice algae (Table 3). 

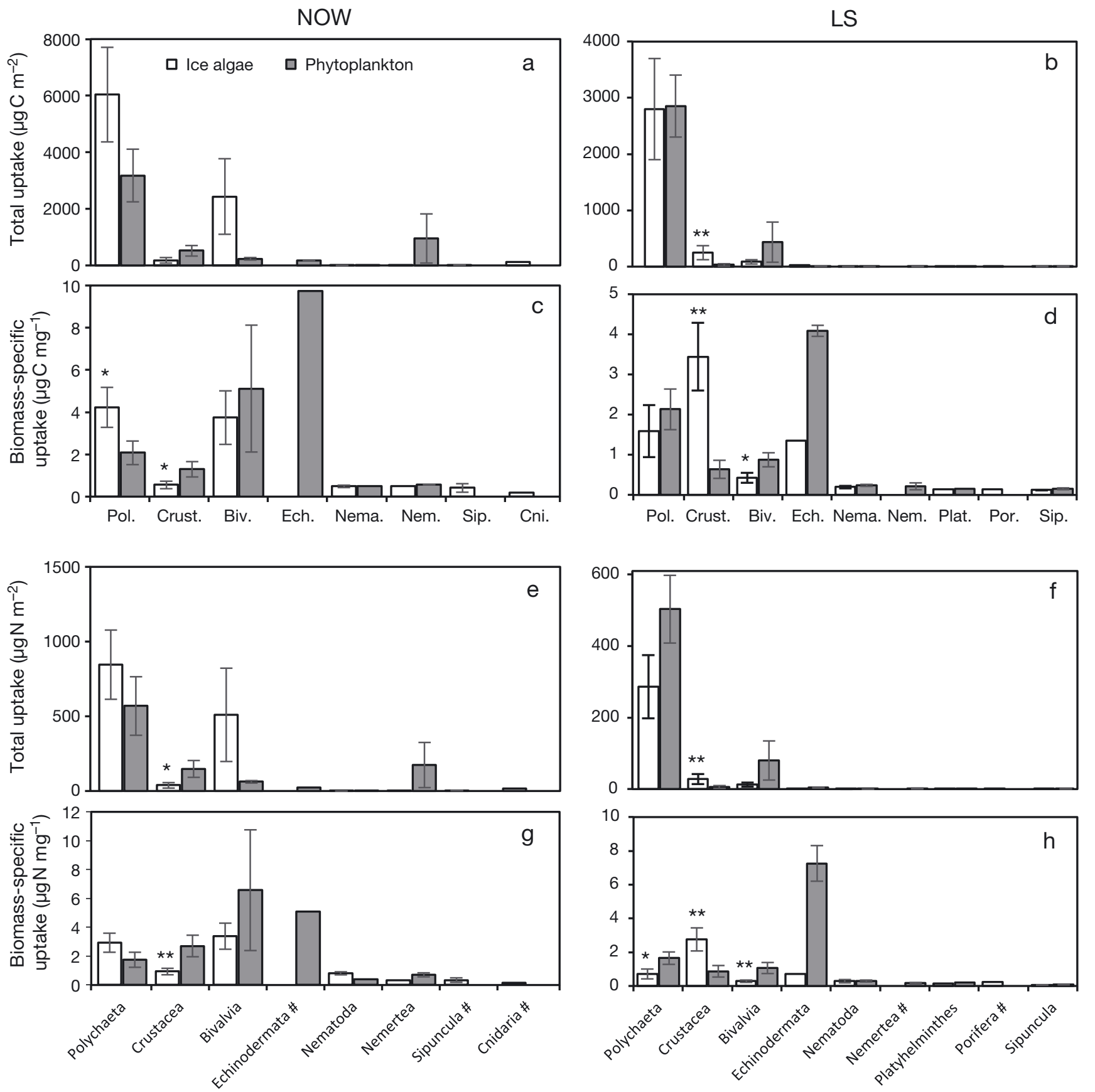

Fig. 3. Mean $( \pm \mathrm{SE})$ total and biomass-specific ice algae and phytoplankton-derived $\mathrm{C}(\mathrm{a}-\mathrm{d})$ and $\mathrm{N}$ (e-h) uptake by major taxa in North Water Polynya (NOW; a,c,e,g) and Lancaster Sound (LS; b, d,f,h). \#: Taxon was only found in one of the treatments. Differences in uptake between the treatments were determined using an independent samples $t$-test or a Mann-Whitney $U$-test (details in Tables $2 \& 3$ ); significant differences are indicated with asterisks: ${ }^{*} \mathrm{p}<0.10 ;{ }^{* *} \mathrm{p}<0.05$. Note differences in $y$-axis scales

\section{Biomass-specific C:N uptake ratio}

Macrofaunal preference for $\mathrm{N}$ and $\mathrm{C}$ was assessed using the ratio of biomass-specific $\mathrm{C}$ to biomassspecific N uptake (Fig. 6). In NOW, the biomassspecific $\mathrm{C}: \mathrm{N}$ uptake ratio of major taxa ranged between 0.5 and 1.4, and in LS the range was 0.6 to 2.2. In relation to the ice algae and phytoplankton C:N ratios (3.95 and 3.52 for ice algae and phytoplankton, respectively), all taxonomic groups appeared to be $\mathrm{N}$-limited and showed a preferential $\mathrm{N}$ uptake compared to $\mathrm{C}$. 

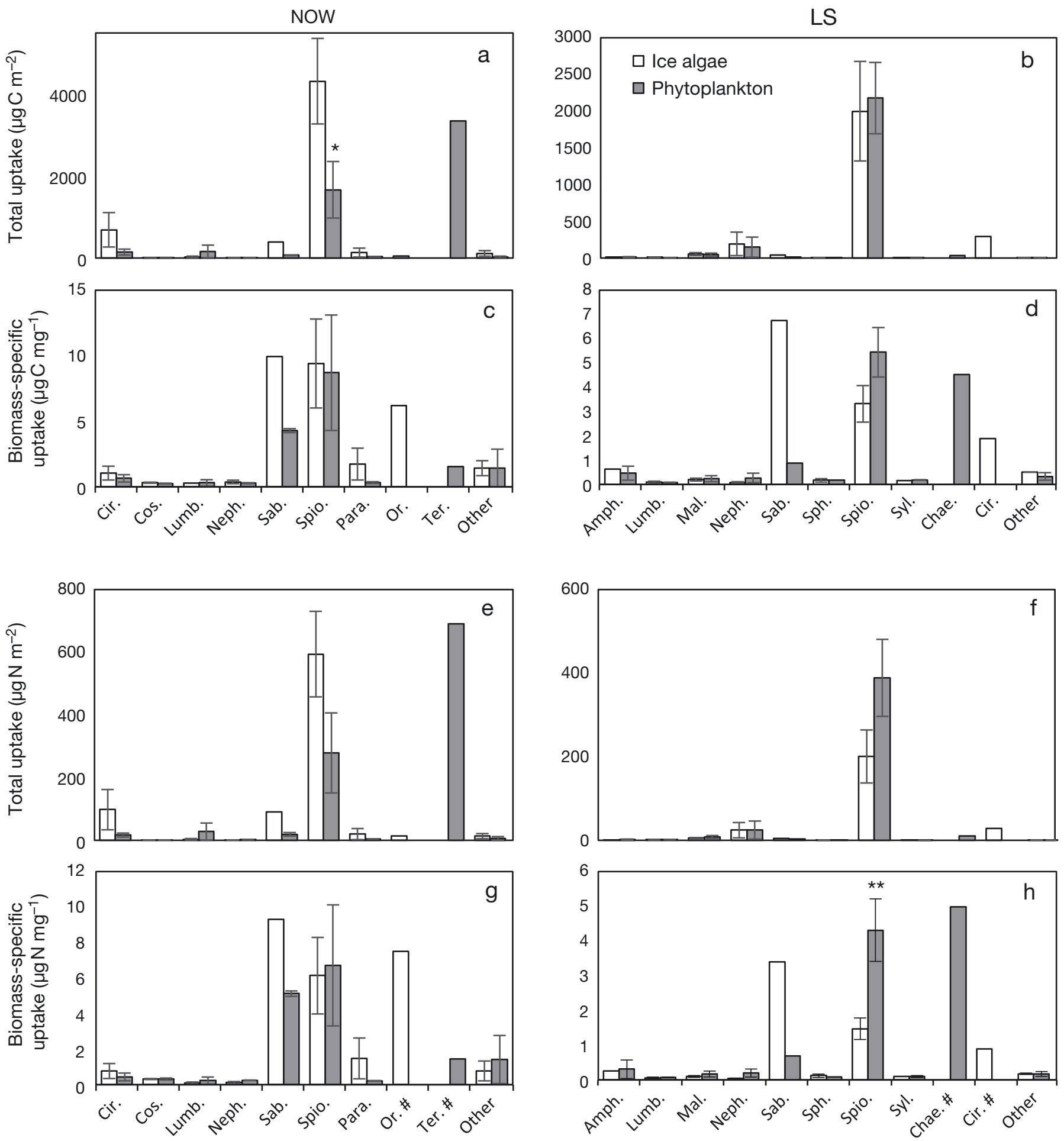

Fig. 4. Mean ( \pm SE) total and biomass-specific ice algae and phytoplankton-derived C (a-d) and N (e-h) uptake by polychaete families at North Water Polynya (NOW; a,c,e,g) and Lancaster Sound (LS; b,d,f,h). 'Other': to pooled rare polychaete families (NOW: Capitellidae, Syllidae, Phyllodocidae and Opheliidae; LS: Acrocirridae, Capitellidae, Cossuridae, Flabelligeridae, Orbiniidae and Terebellidae). Cir: Cirratulidae; Cos: Cossuridae; Lumb: Lumbrineridae; Neph: Nephtyidae; Sab: Sabellidae; Spio: Spionidae; Para: Paraonidae; Or: Orbiniidae; Ter: Terebellidae; Amph: Ampharetidae; Mal: Maldanidae; Sph: Sphaerodoridae; Syl: Syllidae; Chae: Chaetopteridae. \#: family only present in one of the treatments. Differences in Spionidae uptake between treatments were determined using an independent samples $t$-test; significant differences are indicated with asterisks: ${ }^{*} \mathrm{p}<0.10 ;{ }^{* *} \mathrm{p}<0.05$. Note differences in $y$-axis scales 
NOW

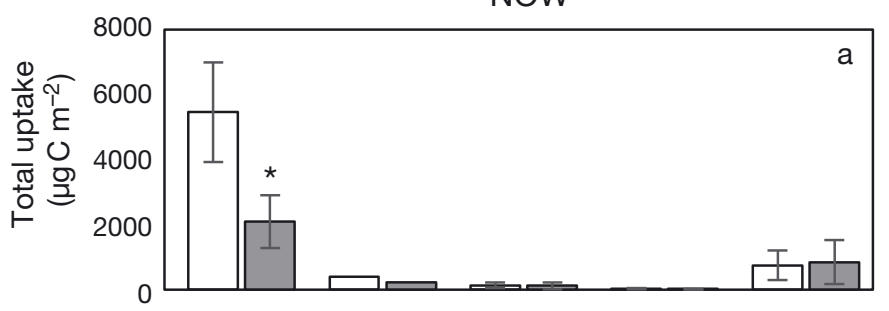

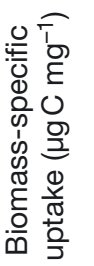
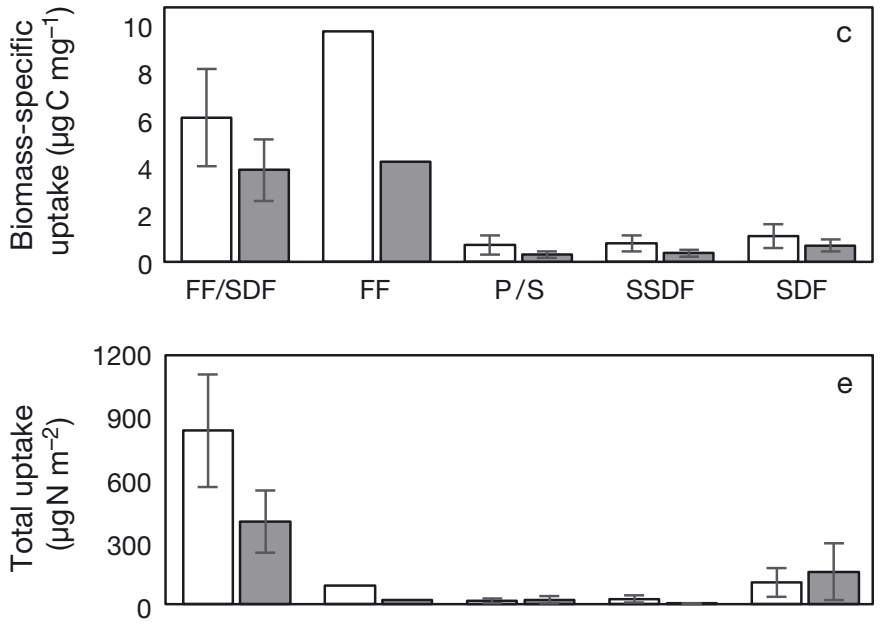

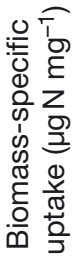

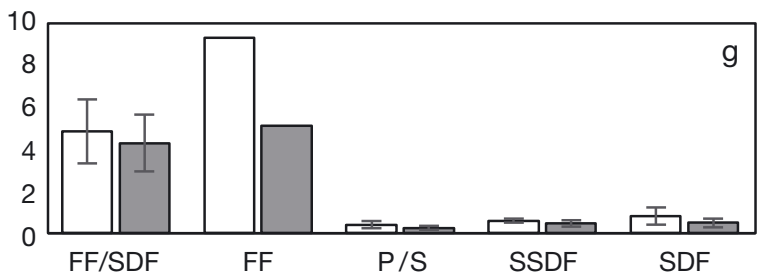

LS
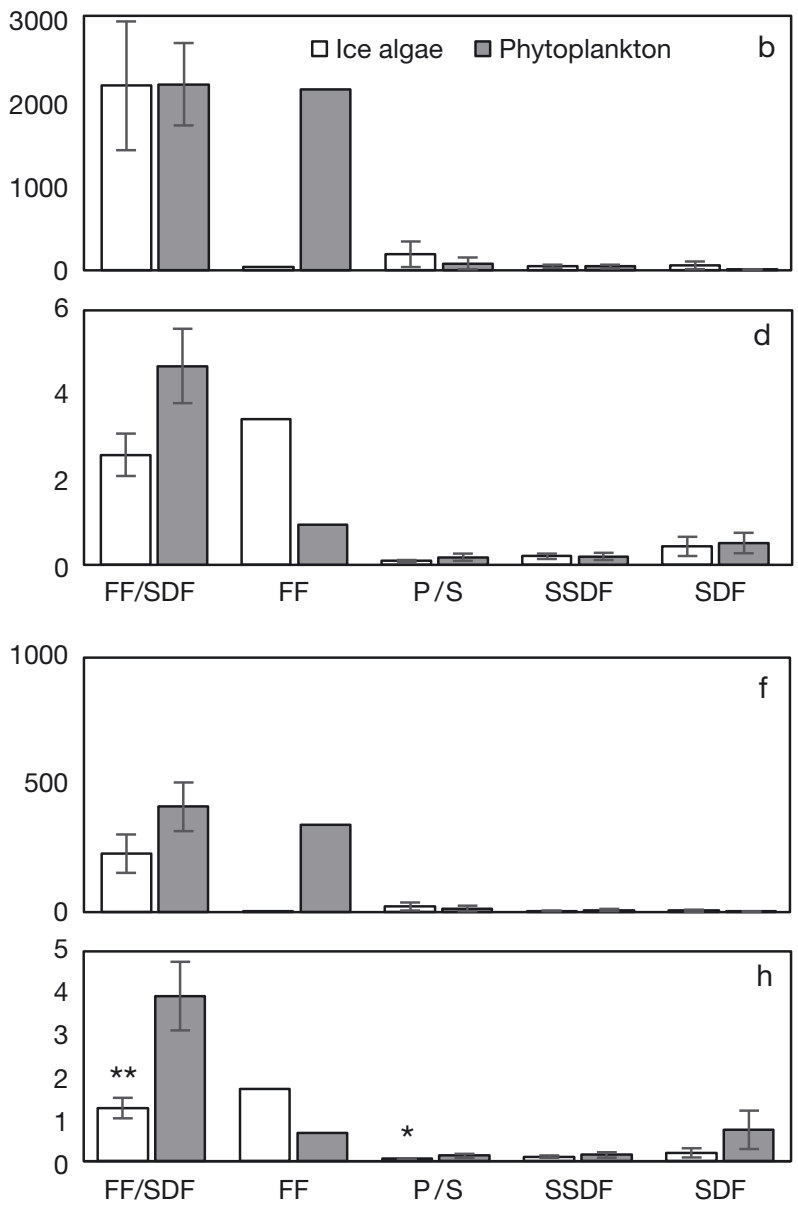

Fig. 5. Mean $( \pm \mathrm{SE})$ total and biomass-specific ice algae and phytoplankton-derived $\mathrm{C}(\mathrm{a}-\mathrm{d})$ and N (e-h) uptake by macroinfaunal feeding guilds in North Water Polynya (NOW; a,c,e,g) and Lancaster Sound $\left(L_{S} ; b, d, f, h\right)$. Differences in uptake between the treatments were determined using an independent samples $t$-test or a Mann-Whitney $U$-test (details in Tables $2 \& 3$ ); significant differences are indicated with asterisks: ${ }^{*} \mathrm{p}<0.10 ;{ }^{* *} \mathrm{p}<0.05$. FF/SDF: facultative filter/surface deposit feeder; FF: filter feeder;

SDF: surface deposit feeder; P/S: predator/scavenger; SSDF: subsurface deposit feeder. Note difference in $y$-axis scales

\section{DISCUSSION}

\section{Responses of macroinfauna to OM pulses}

The responses of the macroinfaunal communities to the pulse of phytodetritus were rapid: virtually all animals in the experimental cores had ingested the added phytodetritus during the $4 \mathrm{~d}$ incubation period. All fauna were thus feeding during the experiments, despite receiving naturally deposited phytodetritus food earlier in the season. This rapid response is in agreement with previous studies that have shown macrofauna to have an important role in the initial processing of $\mathrm{OM}$ deposited on the sea floor (Graf 1989, Blair et al. 1996, Witte et al. 2003b, Kamp \& Witte 2005, Gontikaki et al. 2011). Due to the similarities between the macroinfaunal community compositions at the NOW and LS study sites and the more comprehensive infaunal community inventories by Lalande (2003), the results of the present study are likely to be a good representation of the regional faunal communities and their responses to food pulses. The majority of $\mathrm{C}$ and $\mathrm{N}$ processing at both stations was due to polychaetes and bivalves, known for their sediment processing capacity (Lopez \& Levinton 1987, Sun et al. 1999). Additionally, surface deposit feeders with first access to sinking food are usually the most significant processors of newly deposited OM (Bender \& Davis 1984, Levin et al. 1999, Aberle \& Witte 2003). Here the dominant polychaete, bivalve and crustacean species found at the study sites are all facultative filter/surface deposit feeders (Mäkelä et al. unpubl. data), and their high abundance, as well as feeding mode, was reflected in 


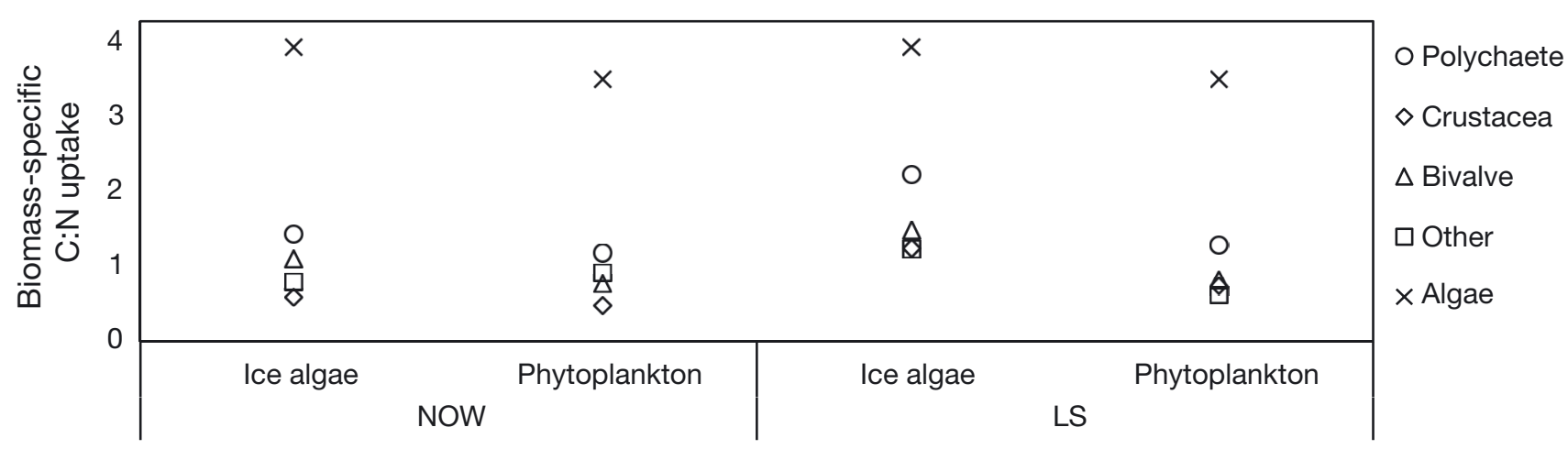

Fig. 6. C:N stoichiometry of the biomass-specific $\mathrm{C}$ and $\mathrm{N}$ uptake of individual taxa in ice algae and phytoplankton treatment cores at North Water Polynya (NOW) and Lancaster Sound (LS) in relation to the C:N ratio of ice algae and phytoplankton

the high $\mathrm{C}$ and $\mathrm{N}$ uptake by this feeding guild overall. The role of other feeding guilds, namely SSDF and $\mathrm{P} / \mathrm{S}$, in the immediate processing of phytodetritus was small. There is, however, usually a time lag before food is mixed into the deeper sediment layers and becomes available to SSDF (Levin et al. 1999), and therefore significant uptake by SSDF after a $4 \mathrm{~d}$ incubation was not likely. Carnivorous macrofauna similarly have a delayed access to the freshly deposited C source (Kamp \& Witte 2005), as the tracer first must be assimilated by suitable prey items before it can be transferred to higher consumers.

The macroinfauna consistently consumed more algae at the NOW station compared to LS, with an uptake nearly twice as high for most measurements. As the algal dose added to the cores reflected local $\mathrm{C}$ export at the 2 study sites, part of the difference is probably due to the higher absolute dose of algae added at NOW, known to enhance benthic activity (Morata et al. 2013). Additionally, macrofaunal biomass is higher at NOW than LS (Mäkelä et al. unpubl. data), which is also likely to contribute to the difference observed. As far as we are aware, the measurements from the 2 study locations provide the first direct quantification of benthic macroinfaunal uptake of fresh algae for the Arctic Ocean. However, this study only provides a snapshot of immediate OM processing after food addition. Seasonality of benthic processes (oxygen consumption, respiration, nutrient fluxes, food uptake) has been shown to be prominent, with highest rates observed straight after a pulse of food to the seafloor during spring or summer (Rysgaard et al. 1998, Brockington et al. 2001, Renaud et al. 2007). This has also been confirmed experimentally by studies that have shown that the majority of macrofaunal activity stimulated by a food pulse takes place immediately after food addition (Witte et al. 2003a, McMahon et al. 2006, Sun et al.
2007, Gontikaki et al. 2011). The responses seem short-lived, with consumption and respiration rates returning to background levels in $19 \mathrm{~d}$ (McMahon et al. 2006) or even after $7 \mathrm{~d}$ as indicated by levels of biomarkers in the sediments (Sun et al. 2007). The short duration of our experiments might also not have allowed for the $\mathrm{C}$ and $\mathrm{N}$ to be fully incorporated into the faunal tissues due to their metabolic rate (Fry 2006) and a fraction of the ingested algae is still probably part of the faunal gut content. This material is also incorporated into the uptake measurement, even if some of it could ultimately be directed towards other metabolic pathways. Therefore the ice algae and phytoplankton uptake rates measured here represent maximum estimates for benthic macroinfauna, and extrapolating these results to long-term processing should be done with great caution, as this may overestimate the role of macroinfauna in the annual C cycling (Woulds et al. 2009). On the other hand, the experiments only measured uptake of the added algal $\mathrm{C}$ and $\mathrm{N}$, and did not assess how much other food the animals might have consumed. As the addition of labile food sources can trigger uptake of preexisting degraded $\mathrm{OM}$ in the sediments (Guenet et al. 2010), it is possible that the fauna met their energetic requirements by ingesting other food sources besides what was deliberately added to the cores. Our hypothesis was, however, set to only test differences in uptake of the added algal sources, and assessing contributions of other food sources is beyond the scope of this study. Still, the macroinfaunal $\mathrm{C}$ uptake rates here appear to exceed previous measurements from incubations carried out on Norwegian fjords sediments (688 to $1200 \mathrm{~m}$, at $7^{\circ} \mathrm{C}$ ) (Witte et al. 2003a, Sweetman \& Witte 2008). Despite the cold bottom water temperatures that are known to slow down macrofaunal OM processing (Moodley et al. 2005), Arctic benthic macrofaunal communities 
can be equally active in their short-term $\mathrm{C}$ uptake as their temperate counterparts.

The biomass-specific C:N uptake ratios of all major taxa investigated in this study fall below the C:N ratio of both ice algae and phytoplankton, suggesting that the taxa investigated are $\mathrm{N}$ limited. Faunal feeding thus appears to be driven by preferential $\mathrm{N}$ uptake as the macrofauna try to maximize their assimilation of algal $\mathrm{N}$ to balance their internal nutrient budgets. Deep-sea macrofauna have previously been shown to adjust their feeding habits to meet their $\mathrm{N}$ requirements (Hunter et al. 2012), and similar decoupling of $\mathrm{C}$ and $\mathrm{N}$ uptake was also prevalent here. The dual labelling thus proved to be a useful method for elucidating the role of internal nutrient demand in controlling macrofaunal uptake of different compounds. But as the $\mathrm{C}: \mathrm{N}$ ratios of the ice algae and phytoplankton used in the experiments were similar, the uptake of one type of algae or the other should not be driven by the algal $\mathrm{N}$ content itself. However, the $\mathrm{C}: \mathrm{N}$ ratios of the algae used in the experiments (3.95 for ice algae and 3.52 for phytoplankton) appear lower than the 5.8 to 8.9 reported for the natural, often nutrient limited, phytoplankton communities in NOW (Tremblay et al. 2002, Mei et al. 2005). The higher nutritional quality of the algae used in the experiments, compared to the algae growing in situ, could therefore have further stimulated macrofaunal uptake compared to natural setting. Furthermore, in the natural setting the phytodetritus can be degraded by water column bacteria while sinking to the seafloor (Roy et al. 2015). Intact algal cells, however, form a majority of the export flux in NOW during early spring when most algal export to the seafloor takes place (Hargrave et al. 2002, Huston \& Deming 2002, Michel et al. 2002a). The bulk of the food that arrives to the seafloor is thus relatively fresh, similar to the added algae, and utilization of laboratory grown algae should not have significantly impacted the outcome of the experiments.

Finally, assimilation of algal $\mathrm{C}$ and $\mathrm{N}$ by the fauna is a minority pathway for the processing of ingested $\mathrm{OM}$ and the majority of the food is often directed towards respiration (McConnaughey \& McRoy 1979, Hunter et al. 2012). While we did not measure faunal respiration rates in this study, the consumption of ice algae and phytoplankton are broadly indicative of the overall trends in respiration of algal-derived $\mathrm{C}$ and $\mathrm{N}$ as well. As the food first has to be ingested before being respired, the significant differences in uptake rates between treatments are probably also reflected in the respiration rates. Additionally, the role of bacteria in processing of the deposited OM can be significant (Gooday 2002, van Oevelen et al. 2006, Sun et al. 2009, Mayor et al. 2012). To fully evaluate the effect of ice algae and phytoplankton on sediment community functioning. The microbial utilization of algae should also be explored.

\section{Whole macroinfaunal community ice algae and phytoplankton uptake trends}

As discussed above, the measurements of the macroinfaunal total $\mathrm{C}$ and $\mathrm{N}$ uptake are useful for assessing the ecological role of fauna in sediment OM processing. Biomass-specific uptake is, however, more robust for testing the hypothesis of differential processing of ice algae and phytoplankton by macrofauna, as it takes into account the variability between core community biomass. The following discussion on the patterns of macrofaunal feeding is therefore based on the biomass-specific uptake results.

In contrast to our original hypothesis, the benthic community ice algal and phytoplankton uptake patterns obtained from the 2 experiments were not the same. We expected ice algae to be more readily taken up at both sites, but interestingly, the 2 faunal communities showed opposite responses to the 2 food types. Overall, the macroinfaunal community at the NOW site appeared to process ice algae more readily, but only the $\mathrm{C}$ uptake was significantly different between the treatments. In LS on the other hand, the uptake of phytoplankton $\mathrm{C}$ and $\mathrm{N}$ was higher than uptake of ice algae. Previous feeding experiments have either found that benthic consumers preferred ice algae or non-preferentially consumed both food items (McMahon et al. 2006, Sun et al. 2007, 2009), and the results of our study are the first to show that the uptake of phytoplankton by benthic macrofauna can exceed rates of ice algal uptake. The different responses of the LS and NOW communities to ice algae and phytoplankton suggests that additional environmental factors, rather than food type alone, drive the macroinfaunal community food selection. To understand these underlying reasons, the individual taxa must be examined in more detail.

\section{Ice algae and phytoplankton uptake by specific taxa}

The responses of the macroinfauna to ice algae and phytoplankton were surprisingly divergent, often exhibiting completely opposite trends between the sites 
but also within the taxa studied. Of the main taxa, crustaceans took up more ice algae in LS, but preferred phytoplankton in NOW, whereas polychaetes took up more phytoplankton $\mathrm{N}$ in LS, but selected more ice algal $\mathrm{C}$ in NOW. Bivalves took up more phytoplankton in LS, but no difference in the algal uptakes was observed in NOW. Therefore the hypothesis that ice algae is the preferred food, which is reflected in a higher rate of uptake compared to phytoplankton, must be rejected based on the 2 experiments.

As many of the polychaetes were only encountered once, or in just one of the treatments, differences in the uptake of the 2 food types by specific polychaete families or species could not be assessed. The only family for which the uptake between the treatments could be compared and differences between the sites contrasted was the facultative FF/SDF Spionidae. This family was abundant at both sites, and the majority of individuals belonged to the species Prionospio cirrifera (Mäkelä et al. unpubl. data). The significance of this single family, or even species, to algal uptake in the experimental cores was unparalleled: the spionids were responsible for $64 \%$ of the total phytoplankton and $62 \%$ of total ice algae uptake by the benthic fauna in LS, and $54 \%$ of the ice algae and $36 \%$ of the phytoplankton uptakes by fauna in NOW, with confirmed $P$. cirrifera individuals taking up 34 to $40 \%$ of all algal $\mathrm{C}$ in the experimental cores. Other studies have similarly observed a single or a few polychaete species (amphinomid Linopherus sp. in Arabian Sea oxygen minimum zone and nereid Ceratocephale sp. and maldanid Praxillella sp. in the North Carolina slope) dominating deep-sea sediment OM processing (Levin et al. 1997, 1999, Woulds et al. 2007), acting as ecosystem engineer species similarly to $P$. cirrifera. Whereas Linopherus sp. was rather inefficient in their biomass-specific OM uptake, dominating the overall processing mainly due their high biomass (Woulds et al. 2007), the Praxillella sp. exhibited processing rates greater than their biomass or abundance might suggest (Levin et al. 1997). The spionids in this study also dominated the biomassspecific uptake, suggesting they are highly efficient in algal uptake. In general, spionids utilized both algal types equally at both sites, except in LS where they had a higher biomass-specific uptake for phytoplankton-derived $\mathrm{N}$ compared to ice algae. Due to the significant role of spionids in the uptake of algae overall, their high rates of phytoplankton processing at LS is the main driver for the entire community uptake pattern observed.

Similarly to spionids, bivalves also took up more phytoplankton in LS, whereas in NOW they fed on both food types equally. It is difficult to say exactly what the reasons behind the differences are, but the environmental conditions at LS could influence the faunal feeding mode, consequently impacting food selection. LS is known for having high current velocities (Thomson 1982), which helps to support a high biomass of filter feeding taxa that utilize the currents to obtain particles suspended in the water column (Thomson 1982, Deubel 2000, Degen et al. 2015). Interestingly, spionids, as well as Thyasiridae bivalves, the most abundant bivalve taxon at LS (Mäkelä et al. unpubl. data), are known to switch from deposit- to filter feeding mode with elevated current speeds (Taghon et al. 1980, MacDonald et al. 2012). Filter feeders usually preferentially feed on phytoplankton, which are more often suspended in the overlying water and thus easier to ingest than large aggregations of ice algae (McConnaughey \& McRoy 1979, Hobson et al. 1995, McMahon et al. 2006). If the environmental conditions at LS promote a filter feeding mode, it could be that the facultative filter feeding spionids and bivalve taxa are more accustomed to feeding on phytoplankton, which might also be reflected in their behavior during the experiments. Furthermore, no differences in the uptake of either food by any of the feeding guilds at NOW was seen, whereas at LS the FF/SDF took up more phytoplankton than ice algae. This also suggests a link between the feeding behavior and food selection of FF/SDF taxa. Interestingly, previous feeding experiments have shown that bivalves have a preference for ice algal food (McMahon et al. 2006, Sun et al. 2009), but the species used in these studies were all classified as either obligate or facultative surface deposit feeders. The selective filter feeding mode in LS could therefore not only explain the high phytoplankton uptake rates of bivalves, but also explain the discrepancy with other studies suggesting ice algae preference.

Previous feeding experiments have shown that benthic crustaceans consume both ice algae and phytoplankton equally (Sun et al. 2009), but in our study the crustaceans showed a clearly elevated uptake of one food item compared to the other, although which food item was more readily taken up depended on the site. The crustacean taxa dominant at the 2 sites (Leuconidae in NOW and Diastylidae in LS; Mäkelä et al. unpubl. data) are both generalist feeders that have the ability to utilize varied food sources. However, previous studies have identified pelagic phytodetritus as the main food source for polar cumaceans, although their food utilization mainly reflected resource availability rather than active food selection (Blazewicz-Paszkowycz \& Ligowski 2002, Würzberg 
et al. 2011). Due to differences in taxonomic compositions between the sites, we cannot ignore the possibility that the differential uptake of the added ice algae and phytoplankton reflects species-specific preferences. The similar background tissue $\delta^{13} \mathrm{C}$ signatures of leuconids and diastylids in NOW and LS, however, suggests that phytoplankton was the shared main food source at both sites (Mäkelä et al. unpubl. data). Therefore, species-specific selectivity is an unlikely explanation for the observed divergent patterns of added algae consumption. Omnivorous sympagic amphipods have, however, been shown to alter their food preferences to reduce intra- and interspecific competition (Poltermann 2001), and a similar strategy could also offer an explanation for the differences seen here. The crustaceans, which have a lower total uptake compared to the other taxa in the experimental cores, might feed on the less utilized resource at each station to reduce competition. This could explain why their uptake of ice algae was higher than uptake of phytoplankton in LS, where the other taxa utilized more phytoplankton, and vice versa for NOW. Additionally, it has been suggested (Sun et al. 2009) and observed (Graeve et al. 2005) that Arctic crustaceans (copepods and amphipods) are able to de novo biosynthesize certain fatty acids they do not obtain from food. If this is the case for other crustaceans too, it might explain why they are less attracted to higher quality food if more effort is required to obtain it, thus supporting the idea that benthic crustacean feeding is unrelated to the availability of specific food items (Sun et al. 2009).

\section{CONCLUSIONS}

The objectives of this study were to (1) quantify the uptake of ice algae and phytoplankton by the benthic macroinfaunal communities, (2) investigate differences in faunal food utilization and (3) examine spatial differences in the responses to ice algae and phytoplankton. The results show that a pulse of OM to the seafloor triggered an immediate response by benthic macroinfauna, regardless of the type of OM added. The fauna efficiently utilized both ice algae and phytoplankton as a food source, and overall algal $\mathrm{C}$ and $\mathrm{N}$ uptake rates appear higher in the Arctic sediment than in temperate deep sea sites. Despite previous studies suggesting macrobenthic communities and individual species either prefer ice algae or non-preferentially consumed both ice algae and phytoplankton, this study is the first to report a higher uptake of phytoplankton compared to ice algae by several Arctic macroinfaunal groups. Individual taxa exhibited great dietary plasticity, and the dominant taxa appeared to change their feeding behavior and food utilization opportunistically to accommodate changes in environmental conditions. Importantly, no taxa exclusively took up significantly more ice algae than phytoplankton, which is a significant finding considering the availability of ice algal food to benthic consumers is likely to decrease in the future. If increasing rates of PP lead to enhanced food availability to benthic consumers, the Arctic benthic macroinfaunal communities could benefit from the proposed projected changes to the quality and the quantity of OM reaching the seafloor. It should, however, be highlighted that these 2 incubation experiments are the first of their kind to be performed in the Canadian Arctic or in Arctic deep-sea environments. Since only 2 experiments generated such contrasting results, it is impossible to make meaningful predictions on how well these findings could be applied locally and ultimately to other Arctic seafloor environments. Additionally, in order to fully understand the impacts of the shift from ice algae to phytoplankton food on benthic functioning as a whole, future work should involve quantifying the rates of other nutrient cycling processes such as respiration, and identifying the role of each benthic compartment in them. However, the results do provide an indication of the adaptability of the seafloor communities to predicted changes in their food supply, which could help safeguard them against the impacts of climate change.

Acknowledgements. We would like to thank the officers and crew of CCGS 'Amundsen' and the ArcticNet scientific and technical personnel for support onboard. We would also like to thank C. Grant (ISMER) and G. Kazanidis (University of Aberdeen) for field assistance, ArcticNet 2013 cruise CTD operators and L. Tréau de Coeli and L. de Montety (ISMER) for macrofauna identification help. Additional thanks go to V. Johnston (University of Aberdeen) for general lab assistance and K. Chalut (ISMER) for sample preparation help. Work was supported by University of Aberdeen The North theme funding for A.M., Natural Environment Research Council ArcDEEP project grant NE/J023094 awarded to U.W. and ArcticNet and Green Edge funding to P.A.

\section{LITERATURE CITED}

Aberle N, Witte U (2003) Deep-sea macrofauna exposed to a simulated sedimentation event in the abyssal $\mathrm{NE}$ Atlantic: in situ pulse-chase experiments using ${ }^{13} \mathrm{C}$ labelled phytodetritus. Mar Ecol Prog Ser 251:37-47

Ambrose WG Jr, Renaud PE (1995) Benthic response to water column productivity patterns: evidence for benthic-pelagic coupling in the Northeast Water Polynya. J Geophys Res 100:4411-4421

Ambrose WG Jr, von Quillfeldt CH, Clough LM, Tilney PVR, 
Tucker T (2005) The sub-ice algal community in the Chukchi sea: large- and small-scale patterns of abundance based on images from a remotely operated vehicle. Polar Biol 28:784-795

Ardyna M, Gosselin M, Michel C, Poulin M, Tremblay JÉ (2011) Environmental forcing of phytoplankton community structure and function in the Canadian High Arctic: contrasting oligotrophic and eutrophic regions. Mar Ecol Prog Ser 442:37-57

Arrigo KR, van Dijken GL (2004) Annual cycles of sea ice and phytoplankton in Cape Bathurst polynya, southeastern Beaufort Sea, Canadian Arctic. Geophys Res Lett 31:2-5

Arrigo KR, van Dijken GL, Pabi S (2008) Impact of a shrinking Arctic ice cover on marine primary production. Geophys Res Lett 35:L19603

Bélanger S, Babin M, Tremblay JÉ (2013) Increasing cloudiness in Arctic damps the increase in phytoplankton primary production due to sea ice receding. Biogeosciences 9:13987-14012

Bender K, Davis WR (1984) The effect of feeding by Yoldia limatula on bioturbation. Ophelia 23:91-100

B Blair NE, Levin LA, Demaster DJ, Plaia G (1996) The shortterm fate of fresh algal carbon in continental slope sediments. Limnol Oceanogr 41:1208-1219

Blazewicz-Paszkowycz M, Ligowski R (2002) Diatoms as food source indicator for some Antarctic Cumacea and Tanaidacea (Crustacea). Antarct Sci 14:11-15

Booth BC, Larouche P, Bélanger S, Klein B, Amiel D, Mei ZP (2002) Dynamics of Chaetoceros socialis blooms in the North Water. Deep Sea Res II 49:5003-5025

Bosley KL, Wainright SC (1999) Effects of preservatives and acidification on the stable isotope ratios $\left({ }^{15} \mathrm{~N}:{ }^{14} \mathrm{~N},{ }^{13} \mathrm{C}:{ }^{12} \mathrm{C}\right)$ of two species of marine animals. Can J Fish Aquat Sci 56:2181-2185

Brockington S, Clarke A, Chapman ALG (2001) Seasonality of feeding and nutritional status during the austral winter in the Antarctic sea urchin Sterechinus neumayeri. Mar Biol 139:127-138

Brown TA, Belt ST (2012) Identification of the sea ice diatom biomarker $\mathrm{IP}_{25}$ in Arctic benthic macrofauna: direct evidence for a sea ice diatom diet in Arctic heterotrophs. Polar Biol 35:131-137

Byrén L, Ejdung G, Elmgren R (2006) Uptake of sedimentary organic matter by the deposit-feeding Baltic amphipods Monoporeia affinis and Pontoporeia femorata. Mar Ecol Prog Ser 313:135-143

Caron G, Michel C, Gosselin M (2004) Seasonal contributions of phytoplankton and fecal pellets to the organic carbon sinking flux in the North Water (northern Baffin Bay). Mar Ecol Prog Ser 283:1-13

Coffin RB, Velinsky DJ, Devereux R, Price WA, Cifuentes LA (1990) Stable carbon isotope analysis of nucleic acids to trace sources of dissolved substrates used by estuarine bacteria. Appl Environ Microbiol 56:2012-2020

Coyle KO, Pinchuk AI (2002) Climate-related differences in zooplankton density and growth on the inner shelf of the southeastern Bering Sea. Prog Oceanogr 55:177-194

Dalsgaard J, St John M, Kattner G, Müller-Navarra D, Hagen W (2003) Fatty acid trophic markers in the pelagic marine environment. Adv Mar Biol 46:225-340

Darnis G, Robert D, Pomerleau C, Link H and others (2012) Current state and trends in Canadian Arctic marine ecosystems. II. Heterotrophic food web, pelagic-benthic coupling, and biodiversity. Clim Change 115:179-205

* Degen R, Vedenin A, Gusky M, Boetius A, Brey T (2015) Patterns and trends of macrobenthic abundance, biomass and production in the deep Arctic Ocean. Polar Res 1: $1-18$

Deubel H (2000) Struktureigenschaften und Nahrungsbedarf der Zoobenthosgemeinschaften im Bereich des Lomonossowrückens im Arktischen Ozean. Ber Polarforsch 370: $1-147$

Falk-Petersen S, Sargent JR, Henderson J, Hegseth EN, Hop H, Okolodkov YB (1998) Lipids and fatty acids in ice algae and phytoplankton from the marginal ice zone in the Barents Sea. Polar Biol 20:41-47

Fauchald K, Jumars P (1979) The diet of worms: a study of polychaete feeding guilds. Oceanogr Mar Biol Annu Rev $17: 193-284$

Forest A, Tremblay JÉ, Gratton Y, Martin J and others (2011) Biogenic carbon flows through the planktonic food web of the Amundsen Gulf (Arctic Ocean): a synthesis of field measurements and inverse modeling analyses. Prog Oceanogr 91:410-436

Fry B (2006) Stable isotope ecology. Springer, New York, NY * Gontikaki E, Mayor DJ, Narayanaswamy BE, Witte U (2011) Feeding strategies of deep-sea sub-Arctic macrofauna of the Faroe-Shetland Channel: combining natural stable isotopes and enrichment techniques. Deep Sea Res I 58: $160-172$

Gooday AJ (2002) Biological responses to seasonally varying fluxes of organic matter to the ocean floor: a review. J Oceanogr 58:305-332

Gosselin M, Levasseur M, Wheeler PA, Horner RA, Booth BC (1997) New measurements of phytoplankton and ice algal production in the Arctic Ocean. Deep Sea Res II 44: 1623-1644

Graeve M, Albers C, Kattner G (2005) Assimilation and biosynthesis of lipids in Arctic Calanus species based on feeding experiments with a ${ }^{13} \mathrm{C}$ labelled diatom. J Exp Mar Biol Ecol 317:109-125

* Graf G (1989) Benthic-pelagic coupling in a deep-sea benthic community. Nature 341:437-439

*Guenet B, Danger M, Abbadie L, Lacroix G (2010) Priming effect: bridging the gap between terrestrial and aquatic ecology. Ecology 91:2850-2861

*Hansen JLS, Josefson AB (2004) Ingestion by depositfeeding macro-zoobenthos in the aphotic zone does not affect the pool of live pelagic diatoms in the sediment. J Exp Mar Biol Ecol 308:59-84

Hargrave BT, Walsh ID, Murray DW (2002) Seasonal and spatial patterns in mass and organic matter sedimentation in the North Water. Deep Sea Res II 49:5227-5244

*Hegseth EN (1998) Primary production of the northern Barents Sea. Polar Res 17:113-123

Hobson KA, Welch HE (1992) Determination of trophic relationships within a high Arctic marine food web using $\delta^{13} \mathrm{C}$ and $\delta^{15} \mathrm{~N}$ analysis. Mar Ecol Prog Ser 84:9-18

Hobson KA, Ambrose WG Jr, Renaud PE (1995) Sources of primary production, benthic-pelagic coupling, and trophic relationships within the Northeast Water Polyna: insights from $\delta^{13} \mathrm{C}$ and $\delta^{15} \mathrm{~N}$ analysis. Mar Ecol Prog Ser 128:1-10

*Hobson KA, Fisk A, Karnovsky N, Holst M, Gagnon JM, Fortier $M(2002)$ A stable isotope $\left(\delta^{13} \mathrm{C}, \delta^{15} \mathrm{~N}\right)$ model for the North Water food web: implications for evaluating trophodynamics and the flow of energy and contaminants. Deep Sea Res II 49:5131-5150

*Horner R, Schrader GC (1982) Relative contributions of ice algae, phytoplankton, and benthic microalgae to primary production in nearshore regions of the Beaufort Sea. Arctic 35:485-503

*Hudson IR, Pond DW, Billett DSM, Tyler PA, Lampitt RS, Wolff GA (2004) Temporal variations in fatty acid com- 
position of deep-sea holothurians: evidence of benthopelagic coupling. Mar Ecol Prog Ser 281:109-120

Hunt GL Jr, Stabeno P, Walters G, Sinclair E, Brodeur RD, Napp JM, Bond NA (2002) Climate change and control of the southeastern Bering Sea pelagic ecosystem. Deep Sea Res II 49:5821-5853

Hunter WR, Levin LA, Kitazato H, Witte U (2012) Macrobenthic assemblage structure and organismal stoichiometry control faunal processing of particulate organic carbon and nitrogen in oxygen minimum zone sediments. Biogeosciences 9:993-1006

Huston AL, Deming JW (2002) Relationships between microbial extracellular enzymatic activity and suspended and sinking particulate organic matter: seasonal transformations in the North Water. Deep Sea Res II 49: 5211-5225

IPCC (2014) Climate change 2014: synthesis report. Contribution of Working Groups I, II and III to the Fifth Assessment Report of the Intergovernmental Panel on Climate Change. IPCC, Geneva

Jónasdóttir SH, Visser AW, Jespersen C (2009) Assessing the role of food quality in the production and hatching of Temora longicornis eggs. Mar Ecol Prog Ser 382:139-150

Kamp A, Witte U (2005) Processing of ${ }^{13} \mathrm{C}$-labelled phytoplankton in a fine-grained sandy-shelf sediment (North Sea): relative importance of different macrofauna species. Mar Ecol Prog Ser 297:61-70

Kaufman MR, Gradinger RR, Bluhm BA, O'Brien DM (2008) Using stable isotopes to assess carbon and nitrogen turnover in the Arctic sympagic amphipod Onisimus litoralis. Oecologia 158:11-22

Kędra M, Moritz C, Choy ES, David C and others (2015) Status and trends in the structure of Arctic benthic food webs. Polar Res 34:23775

Kenchington EL, Link H, Roy V, Archambault P, Siferd T, Treble M, Wareham V (2011) Identification of mega- and macrobenthic ecologically and biologically significant areas (EBSAs) in the Hudson Bay Complex, the western and eastern Canadian Arctic. Canadian Science Advisory Secretariat, Research Document 2011/071. Department of Fisheries and Oceans, Ottawa

Kirchman DL, Malmstrom RR, Cottrell MT (2005) Control of bacterial growth by temperature and organic matter in the Western Arctic. Deep Sea Res II 52:3386-3395

Klein B, LeBlanc B, Mei ZP, Beret R and others (2002) Phytoplankton biomass, production and potential export in the North Water. Deep Sea Res II 49:4983-5002

Lalande C (2003) Composition et structure de la communauté benthique et quantification de la bioturbation dans la polynie des Eaux du Nord. MSc thesis, Institut des sciences de la mer de Rimouski, Université du Québec à Rimouski, Rimouski

Lalande C, Forest A, Barber DG, Gratton Y, Fortier L (2009) Variability in the annual cycle of vertical particulate organic carbon export on Arctic shelves: contrasting the Laptev Sea, Northern Baffin Bay and the Beaufort Sea. Cont Shelf Res 29:2157-2165

* Leu E, Søreide JE, Hessen DO, Falk-Petersen S, Berge J (2011) Consequences of changing sea-ice cover for primary and secondary producers in the European Arctic shelf seas: timing, quantity, and quality. Prog Oceanogr 90:18-32

Keu E, Mundy CJ, Assmy P, Campbell K and others (2015) Arctic spring awakening - steering principles behind the phenology of vernal ice algal blooms. Prog Oceanogr 139:151-170

Levin L, Blair N, DeMaster D, Plaia G, Fornes W, Martin C,
Thomas C (1997) Rapid subduction of organic matter by maldanid polychaetes on the North Carolina slope. J Mar Res 55:595-611

* Levin LA, Blair NE, Martin CM, Demaster DJ, Plaia G, Thomas CJ (1999) Macrofaunal processing of phytodetritus at two sites on the Carolina margin: in situ experiments using ${ }^{13} \mathrm{C}$-labeled diatoms. Mar Ecol Prog Ser 182: $37-54$

Link H, Chaillou G, Forest A, Piepenburg D, Archambault P (2013a) Multivariate benthic ecosystem functioning in the Arctic-benthic fluxes explained by environmental parameters in the southeastern Beaufort Sea. Biogeosciences 10:5911-5929

KLink H, Piepenburg D, Archambault P (2013b) Are hotspots always hotspots? The relationship between diversity, resource and ecosystem functions in the Arctic. PLOS ONE 8:e74077

KLopez GR, Levinton JS (1987) Ecology of deposit-feeding animals in marine sediments. Q Rev Biol 62:235-260

* Lovejoy C, Legendre L, Martineau MJ, Bacle J, von Quillfeldt CH (2002) Distribution of phytoplankton and other protists in the North Water. Deep Sea Res II 49: 5027-5047

* Lovvorn JR, Cooper LW, Brooks ML, De Ruyck CC, Bump JK, Grebmeier JM (2005) Organic matter pathways to zooplankton and benthos under pack ice in late winter and open water in late summer in the north-central Bering Sea. Mar Ecol Prog Ser 291:135-150

* Lovvorn J, North C, Kolts J, Grebmeier JM, Cooper L, Cui X (2016) Projecting the effects of climate-driven changes in organic matter supply on benthic food webs in the northern Bering Sea. Mar Ecol Prog Ser 548:11-30

MacDonald TA, Burd BJ, van Roodselaar A (2012) Facultative feeding and consistency of trophic structure in marine soft-bottom macrobenthic communities. Mar Ecol Prog Ser 445:129-140

* Mateo MA, Serrano O, Serrano L, Michener RH (2008) Effects of sample preparation on stable isotope ratios of carbon and nitrogen in marine invertebrates: implications for food web studies using stable isotopes. Oecologia 157:105-115

* Mayor DJ, Thornton B, Hay S, Zuur AF, Nicol GW, McWilliam JM, Witte U (2012) Resource quality affects carbon cycling in deep-sea sediments. ISME J 6: 1740-1748

McConnaughey T, McRoy CP (1979) Food-web structure and the fractionation of carbon isotopes in the Bering Sea. Mar Biol 53:257-262

McMahon KW, Ambrose WG Jr, Johnson BJ, Sun MY, Lopez GR, Clough LM, Carroll ML (2006) Benthic community responses to ice algae and phytoplankton in Ny Ålesund, Svalbard. Mar Ecol Prog Ser 310:1-14

McTigue ND, Dunton KH (2014) Trophodynamics and organic matter assimilation pathways in the northeast Chukchi Sea, Alaska. Deep Sea Res II 102:84-96

* Mei ZP, Legendre L, Tremblay JÉ, Miller LA and others (2005) Carbon to nitrogen (C:N) stoichiometry of the spring-summer phytoplankton bloom in the North Water Polynya (NOW). Deep Sea Res I 52:2301-2314

*Michel C, Gosselin M, Nozais C (2002a) Preferential sinking export of biogenic silica during the spring and summer in the North Water Polynya (northern Baffin Bay): temperature or biological control? J Geophys Res 107:3064

Michel C, Nielsen TG, Nozais C, Gosselin M (2002b) Significance of sedimentation and grazing by ice micro- and meiofauna for carbon cycling in annual sea ice (northern Baffin Bay). Aquat Microb Ecol 30:57-68 
Michel C, Ingram RG, Harris LR (2006) Variability in oceanographic and ecological processes in the Canadian Arctic Archipelago. Prog Oceanogr 71:379-401

* Monroig Ó, Tocher DR, Navarro JC (2013) Biosynthesis of polyunsaturated fatty acids in marine invertebrates: recent advances in molecular mechanisms. Mar Drugs 11:3998-4018

Moodley L, Middelburg JJ, Soetaert K, Boschker HTS, Herman PMJ, Heip CHR (2005) Similar rapid response to phytodetritus deposition in shallow and deep-sea sediments. J Mar Res 63:457-469

Morata N, Michaud E, Włodarska-Kowalczuk M (2013) Impact of early food input on the Arctic benthos activities during the polar night. Polar Biol 38:99-114

North CA, Lovvorn JR, Kolts JM, Brooks ML, Cooper LW, Grebmeier JM (2014) Deposit-feeder diets in the Bering Sea: potential effects of climatic loss of sea ice-related microalgal blooms. Ecol Appl 24:1525-1542

Overland JE, Wang M (2013) When will the summer Arctic be nearly sea ice free? Geophys Res Lett 40:2097-2101

Pabi S, van Dijken GL, Arrigo KR (2008) Primary production in the Arctic Ocean, 1998-2006. J Geophys Res Oceans 113:C08005

* Poltermann M (2001) Arctic sea ice as feeding ground for amphipods - food sources and strategies. Polar Biol 24: 89-96

Quinn GP, Keough MJ (2002) Experimental design and data analysis for biologists. Cambridge University Press, Cambridge

Renaud PE, Riedel A, Michel C, Morata N, Gosselin M, JuulPedersen T, Chiuchiolo A (2007) Seasonal variation in benthic community oxygen demand: a response to an ice algal bloom in the Beaufort Sea, Canadian Arctic? J Mar Syst 67:1-12

Roy V, Iken $\mathrm{K}$, Gosselin M, Tremblay JÉ, Bélanger $\mathrm{S}$, Archambault P (2015) Benthic faunal assimilation pathways and depth-related changes in food-web structure across the Canadian Arctic. Deep Sea Res I 102:55-71

Rysgaard S, Thamdrup B, Risgaard-Petersen N, Fossing H, Berg P, Christensen PB, Dalsgaard T (1998) Seasonal carbon and nutrient mineralization in a high-Arctic coastal marine sediment, Young Sound, Northeast Greenland. Mar Ecol Prog Ser 175:261-276

Sarakinos HC, Johnson ML, Vander Zanden MJ (2002) A synthesis of tissue-preservation effects on carbon and nitrogen stable isotope signatures. Can J Zool 80:381-387

Søreide JE, Leu E, Berge J, Graeve M, Falk-Petersen S (2010) Timing of blooms, algal food quality and Calanus glacialis reproduction and growth in a changing Arctic. Glob Change Biol 16:3154-3163

Søreide JE, Carroll ML, Hop H, Ambrose WG Jr, Hegseth EN, Falk-Petersen S (2013) Sympagic-pelagic-benthic coupling in Arctic and Atlantic waters around Svalbard revealed by stable isotopic and fatty acid tracers. Mar Biol Res 9:831-850

Stirling I (1980) The biological importance of polynyas in the Canadian Arctic. Arctic 33:303-315

Sun MY, Aller RC, Lee C, Wakeham SG (1999) Enhanced degradation of algal lipids by benthic macrofaunal activity: effect of Yoldia limatula. J Mar Res 57:775-804

Sun MY, Carroll ML, Ambrose WG Jr, Clough LM, Zou L, Lopez GR (2007) Rapid consumption of phytoplankton and ice algae by Arctic soft-sediment benthic communities: evidence using natural and ${ }^{13} \mathrm{C}$-labeled food materials. J Mar Res 65:561-588

Sun MY, Clough LM, Carroll ML, Dai J, Ambrose WG Jr, Lopez GR (2009) Different responses of two common
Arctic macrobenthic species (Macoma balthica and Monoporeia affinis) to phytoplankton and ice algae: Will climate change impacts be species specific? J Exp Mar Biol Ecol 376:110-121

* Sweetman AK, Witte U (2008) Macrofaunal response to phytodetritus in a bathyal Norwegian fjord. Deep Sea Res I 55:1503-1514

Taghon GL, Nowell ARM, Jumars PA (1980) Induction of suspension feeding in spionid polychaetes by high particulate fluxes. Science 210:562-564

*Tamelander T, Reigstad M, Hop H, Ratkova T (2009) Ice algal assemblages and vertical export of organic matter from sea ice in the Barents Sea and Nansen Basin (Arctic Ocean). Polar Biol 32:1261-1273

Thomson DH (1982) Marine benthos in the eastern Canadian High Arctic: multivariate analyses of standing crop and community structure. Arctic 35:61-74

*Tremblay JÉ, Gratton Y, Fauchot J, Price NM (2002) Climatic and oceanic forcing of new, net, and diatom production in the North Water. Deep Sea Res II 49: 4927-4946

* Tremblay JÉ, Hattori H, Michel C, Ringuette M and others (2006) Trophic structure and pathways of biogenic carbon flow in the eastern North Water Polynya. Prog Oceanogr 71:402-425

*van Oevelen D, Soetaert K, Middelburg JJ, Herman PMJ and others (2006) Carbon flows through a benthic food web: integrating biomass, isotope and tracer data. J Mar Res 64:453-482

von Quillfeldt CH (1997) Distribution of diatoms in the Northeast Water Polynya, Greenland. J Mar Syst 10:211-240

* von Quillfeldt CH, Ambrose WG Jr, Clough LM (2003) High number of diatom species in first-year ice from the Chukchi Sea. Polar Biol 26:806-818

Wang SW, Budge SM, Gradinger RR, Iken K, Wooller MJ (2014) Fatty acid and stable isotope characteristics of sea ice and pelagic particulate organic matter in the Bering Sea: tools for estimating sea ice algal contribution to Arctic food web production. Oecologia 174:699-712

* Welch HE, Bergmann MA, Siferd TD, Martin KA and others (1992) Energy flow through the marine ecosystem of the Lancaster South Region, Arctic Canada. Arctic 45: 343-357

Witte U, Wenzhöfer F, Sommer S, Boetius A and others (2003a) In situ experimental evidence of the fate of a phytodetritus pulse at the abyssal sea floor. Nature 424: 763-766

Witte U, Aberle N, Sand M, Wenzhöfer F (2003b) Rapid response of a deep-sea benthic community to POM enrichment: an in situ experimental study. Mar Ecol Prog Ser 251:27-36

Woulds C, Cowie GL, Levin LA, Andersson JH and others (2007) Oxygen as a control on seafloor biological communities and their roles in sedimentary carbon cycling. Limnol Oceanogr 52:1698-1709

*Woulds C, Andersson JH, Cowie GL, Middelburg JJ, Levin LA (2009) The short-term fate of organic carbon in marine sediments: comparing the Pakistan margin to other regions. Deep Sea Res II 56:393-402

Würzberg L, Peters J, Brandt A (2011) Fatty acid patterns of Southern Ocean shelf and deep sea peracarid crustaceans and a possible food source, foraminiferans. Deep Sea Res II 58:2027-2035

Yokoyama H, Tamaki A, Harada K, Shimoda K, Koyama K, Ishihi Y (2005) Variability of diet-tissue isotopic fractionation in estuarine macrobenthos. Mar Ecol Prog Ser 296: $115-128$ 